\title{
Directional responses following recombinant cytokine stimulation of rainbow trout (Oncorhynchus mykiss) RTS- I I macrophage cells as revealed by transcriptome profiling
}

\author{
Samuel AM Martin*, Jun Zou, Dominic F Houlihan and \\ Christopher J Secombes
}

Address: Scottish Fish Immunology Research Centre, School of Biological Sciences, University of Aberdeen, Tillydrone Avenue, Aberdeen, AB24 2TZ, UK

Email: Samuel AM Martin* - sam.martin@abdn.ac.uk; Jun Zou - j.zou@abdn.ac.uk; Dominic F Houlihan - d.f.houlihan@abdn.ac.uk; Christopher J Secombes - c.secombes@abdn.ac.uk

* Corresponding author

Published: 7 June 2007

BMC Genomics 2007, 8:150 doi:10.1 |86/I47|-2/64-8-150

This article is available from: http://www.biomedcentral.com/I47|-2/64/8//50

(c) 2007 Martin et al; licensee BioMed Central Ltd.

This is an Open Access article distributed under the terms of the Creative Commons Attribution License (http://creativecommons.org/licenses/by/2.0), which permits unrestricted use, distribution, and reproduction in any medium, provided the original work is properly cited.

\begin{abstract}
Background: The early stages of the immune response are regulated by key cytokines including both interleukin I $\beta$ (IL-I $\beta$ ) and interferon- $\gamma(\mathrm{IFN}-\gamma)$ which stimulate panels of responsive genes via conserved signal transduction pathways. To further our understanding of the transcriptional response to these cytokines in lower vertebrates we have utilized microarray analysis to characterize the transcriptional response to recombinant rainbow trout IL-I $\beta$ and IFN- $\gamma$ in the trout macrophage cell line RTS-I I.
\end{abstract}

Results: RNA was extracted from stimulated or control cells following $6 \mathrm{~h}$ incubation and used to hybridize to a salmonid cDNA microarray containing 16,006 different genes. Analysis of the arrays revealed mRNA transcripts that were differentially expressed as a result of exposure to the recombinant proteins, with some responses common for both cytokines. In general the recombinant IL-I $\beta$ elicited a response where genes involved in the acute phase response were upregulated, whilst the recombinant IFN- $\gamma$ induced strong up-regulation of genes involved in the MHC class I antigen presentation pathway. Key genes were chosen that were differentially regulated and analysed by real time PCR at additional time points, up to $48 \mathrm{~h}$ following stimulation. This allowed a deeper insight into the kinetics of the response to the cytokines in this cell line.

Conclusion: We demonstrated that in fish both rIL-I $\beta$ and rIFN- $\gamma$ stimulated discrete panels of mRNA transcripts which indicted the cells were being directed towards different cellular functions, with IL- $\beta$ inducing genes involved in the inflammatory response, whereas IFN- $\gamma$ induced genes associated with antigen presentation.

\section{Background}

The sequencing of several fish genomes including pufferfish [1], Tetraodon [2], zebrafish [3], medaka and stickleback (current status reviewed in [4]) has had a tremendous impact on gene discovery within fish. One example is within the immune system, where until recently very few cytokine genes had been discovered using homology cloning or EST analyses [5], but now a 
large number are known from a wide variety of species including trout, salmon, carp and zebrafish amongst others, and including many interleukins e.g. IL-1 [6,7], IL-2 [8], IL-6 [9], IL-8 [10], IL-10 [11], IL-11 [12], type 1 and type 2 interferons [13-15], lymphotoxin $\beta$ [16], transforming growth factors [17], chemokines [18,19], as well as some with no obvious homology to known mammalian cytokines. Whilst it is possible to assume the function of cytokines with clear homology to know genes, this is not possible when homology is lacking, and in such cases empirical data is needed on bioactivity. Even when homology is apparent, bioactivity should be confirmed in fish where significant differences in physiology exist.

Advances in functional genomics methodologies now allow the simultaneous measurement of the expression of many thousands of genes, using microarrays. Arrays for fish are becoming increasingly available, and for salmonid fish have been extremely useful in analysing the host transcriptional responses to bacterial [20-23] viral [24], parasitic [25] and fungal infections [26]. Additionally transcriptome analysis has been used to study the response of fish to vaccination $[27,28]$ or stimulation with molecules such as LPS [29]. The microarrays used in the above studies use both cDNA and oligo array type platforms.

To date very few fish cytokines have been produced as recombinant proteins for bioactivity testing. The main exceptions are interleukin-1 $\beta$ [30], TNF $\alpha$ [31] and the interferons $[13,14]$. In these cases the examination of their function has been rather narrow with the impact on only one or two genes typically examined. In this study two of these cytokines are studied using functional genomics approaches, to give a broad overview of their effect on a large number of genes, to confirm if their predicted effects hold when examined in this way and to give a framework for future studies using cytokines with no clear homology. The two cytokines used are interferon gamma (IFN- $\gamma$ ) and interleukin-1beta (IL-1 $\beta$ ), which are expected to have very different biological activities.

Both IL-1 $\beta$ and IFN- $\gamma$ are cytokines that are key for the early response of the immune system, and as such are key in understanding how cells are directed. IL- $1 \beta$ is a pro inflammatory cytokine directly stimulating the innate immune system [32] and during later stages of infection has major roles in the activation of T and B cells [33]. It is produced as a precursor molecule that is cleaved to generate a mature peptide. It is only active as the mature molecule and can affect most cells and organ systems. There are two primary cell surface receptors that bind the mature IL$1 \beta$, type I and type II. When IL- $1 \beta$ binds to the type I receptor, a complex is formed that binds to the IL-1R accessory protein (IL-1RacP), resulting in high affinity binding [34] and a subsequent cascade of signalling that results in transcription factors binding to target genes initiating or decreasing their expression. This signalling pathway is shared with the Toll like receptor signalling pathway via myeloid-differentiation marker (MyD88) and subsequently nuclear factor- $\kappa \beta(\mathrm{NF}-\kappa \beta)$ and mitogenactivated protein kinases [35]. In contrast the type II receptor does not transduce a signal and acts as a sink for IL-1 $\beta$ and may be regarded as a decoy receptor [36].

IFN- $\gamma$ was originally identified as an antiviral factor but also has central roles in activation of macrophages, stimulation of antigen presentation through class I and class II major histocompatibility complex (MHC) molecules [37] and regulation of $\mathrm{T}$ cell differentiation [38]. IFN- $\gamma$ is produced by natural killer cells and $\mathrm{T}$ lymphocytes in response to IL-12 and IL-18 [39]. In its active form the cytokine binds to the IFN- $\gamma$ receptors $\mathrm{R} 1$ and $\mathrm{R} 2$ which activate the intracellular JAK/STAT signal pathway to initiate the expression of a large number of different genes [40]. One effect is to induce macrophages to produce toxic substances, including reactive oxygen intermediates, to kill intracellular bacteria and exert antiviral activities by inducing a number of antiviral proteins such as 2', 5'-oligoadenylate synthetase, dsRNA-dependant protein kinase $\mathrm{PKR}$, guanylate binding protein and adenosine deaminase [40]. IFN- $\gamma$ can also stimulate expression of other cytokines that activate and induce proliferation of CD4+ cells [41]. Thus IFN- $\gamma$ makes a major contribution to the Th1 induced cell mediated immune response, mainly controlled by mutual feed back between IFN- $\gamma$ and IL-12 [42].

The macrophage response to infection and activation by immune stimulants can be effectively analysed by microarray analysis allowing thousands of genes to be monitored for expression in parallel. This can be seen by the number of studies on mammalian (reviewed [43]) and avian [44] macrophage microarray studies. The methods employed by pathogens to evade the immune system are complex and by studying specific cell types or tissues the host defence strategies can be examined. To further characterise the response, specific cytokines have been used to stimulate human [45], murine [46] and bovine [47] macrophage cell lines. In addition the gene expression response of $\mathrm{T}$ cells to PAMPS has been explored using microarrays [48].

Recently, both IL-1 $\beta$ [6] and IFN- $\gamma$ [14] have been cloned and sequenced from rainbow trout in our laboratory and recombinant proteins produced to study their respective functions $[14,30]$. Thus it is possible to study for the first time the genes that are responsive to these two key cytokines on a transcriptome wide scale in a lower vertebrate. Stimulations were performed with a rainbow trout 
macrophage cell line RTS-11 [49], expected to be highly responsive to both cytokines, as the model used, to keep intra assay variation low and to allow maximal power to the subsequent data analysis. A 16,006 feature salmonid microarray [50] was used to identify genes that were altered in expression as a result of stimulation with these recombinant cytokines, with the prediction that differential gene profiles would be induced that indicate a bias towards innate or adaptive immunity. This platform has previously been demonstrated to be useful in the transcriptional analysis during infection and immune response in salmonid fish $[25,26]$.

\section{Results \\ Cell stimulation}

To dissect the immunomodulatory effects of the rainbow trout recombinant proteins on RTS-11 cells, the cells were treated with either $20 \mathrm{ng} \mathrm{ml}^{-1}$ rIL-1 $\beta$ or rIFN- $\gamma$ protein. Control cells were unstimulated. Prior to microarray analysis rt PCR was performed using genes known to be stimulated by these cytokines with samples taken at $6 \mathrm{~h}$ post stimulation. For IL- $1 \beta$, IL- $1 \beta$ and IL- 8 expression were induced, whilst for IFN- $\gamma$, $\gamma$ IP [51] was shown to be increased in expression, confirming the cells were responding to the stimulation (data not shown). On the basis of these results the RNA was used to continue with the microarray experiment and time course response. Later time points were not examined by microarray to avoid confounding effects of indirect actions of the two cytokines, with $6 \mathrm{~h}$ considered optimal for direct effects of both based on our previous studies (see methods).

\section{Microarray analysis}

The salmonid cDNA microarray developed by von Schalburg et al. [50] that contained 13,421 Atlantic salmon and 2,576 rainbow trout cDNAs was used in this study. Characterization of this microarray [50], demonstrated that rainbow trout cDNA hybridizes well even though the majority of sequences are for Atlantic salmon, because of the very high level of sequence conservation between these two species. A total of $5963( \pm 347$ SEM) features had a signal that was greater than the background threshold to be included in the working data set.

For the IFN- $\gamma$ experiment, 34 cDNA features were found to be significantly increased 2 fold or greater and 8 genes down regulated using the same criteria. For cells stimulated with IL-1ß, 92 genes were increased and 7 decreased. Fifteen of the genes altered in expression were common between the two cytokine stimulations. Fewer cDNA features were down regulated for cells stimulated with rIFN$\gamma$ and rIL-1 $\beta$, indicating that the cytokine stimulation at 6 $h$ has a predominantly positive effect on gene transcription. The cDNAs that were found to be differentially expressed by the microarray analysis are shown in Table 2 .
The majority of CDNA identities were assigned on the GAL file [50], however $28 \%$ of clones were unidentified. To assign further identity to these unknowns the "Unigene" sets were utilized [52]. For salmon and rainbow trout 21,841 and 23,359 Uni genes have been determined to date (26/09/06). Here ESTs have been clustered and BlastX performed on the longest cDNA in the cluster [53]. The identities that were directly from the UNI gene sets are marked in Table 2. UniGene clusters with no functional protein assigned to them are given the UniGene code which may help in future identification. Genes that do not have a functional protein or a UniGene cluster are termed unknown, indicating they only occur once in the data base. Of the cDNAs that are found to be altered $91 \%$ and $71 \%$ for rIFN- $\gamma$ and rIL- $1 \beta$ respectively were found to have identities with functional proteins. All cDNAs that had a functional protein identity had gene ontology identifiers assigned to them and were grouped according to gene ontology function. Gene ontology of up regulated genes are shown in Fig. 1.

Of the four cDNA features from the IFN- $\gamma$ set with no identified homologue, 3 of these were members of clusters as assigned by NCBI UniGene and one was a singleton that did not match any other sequence in the data bases. For the IL-1 $\beta$ group of the 27 with no protein identity, 19 were in clusters with four found to be singletons.

Fourteen identified genes and one cluster [NCBI:Ssa.15825] were found to be up regulated by both IL- $1 \beta$ and IFN- $\gamma$ and included a range of encoded proteins. The magnitude of response, in terms of the level of expression of genes affected by both cytokines, was markedly different between the two stimulations. This is clearly seen for the $C$ type lectins which are dramatically stimulated by IL-1 $\beta$ (18 fold) whilst they are increased 6.5 fold by IFN$\gamma$. Several of the key genes involved in the IFN- $\gamma$ signalling pathway are strongly up-regulated in cells stimulated with IFN- $\gamma$, such as IRF- 1 ( $\times 12$ increase) and an IRF-8 homologue ( $\times 10$ increase). In contrast IRF- 1 was only increased 3 fold after IL-1 $\beta$ stimulation. For down regulated genes, one gene was decreased by both cytokines, referred to as ID2 protein. This protein is involved in inhibition of protein binding to DNA and as such could be described as an inhibitor of DNA transcription [54].

\section{Real time PCR confirmation of expression}

Real time PCR was used to confirm the expression of a subset of genes found to be differentially expressed during the microarray hybridizations at $6 \mathrm{~h}$ post stimulation. Initial real time PCR products were separated on $2 \%$ agarose gels and viewed under UV to confirm only a single product of the predicted size was being amplified. The primer sets were used for cDNA from both stimulations to add additional information not obtained from the microarray, 


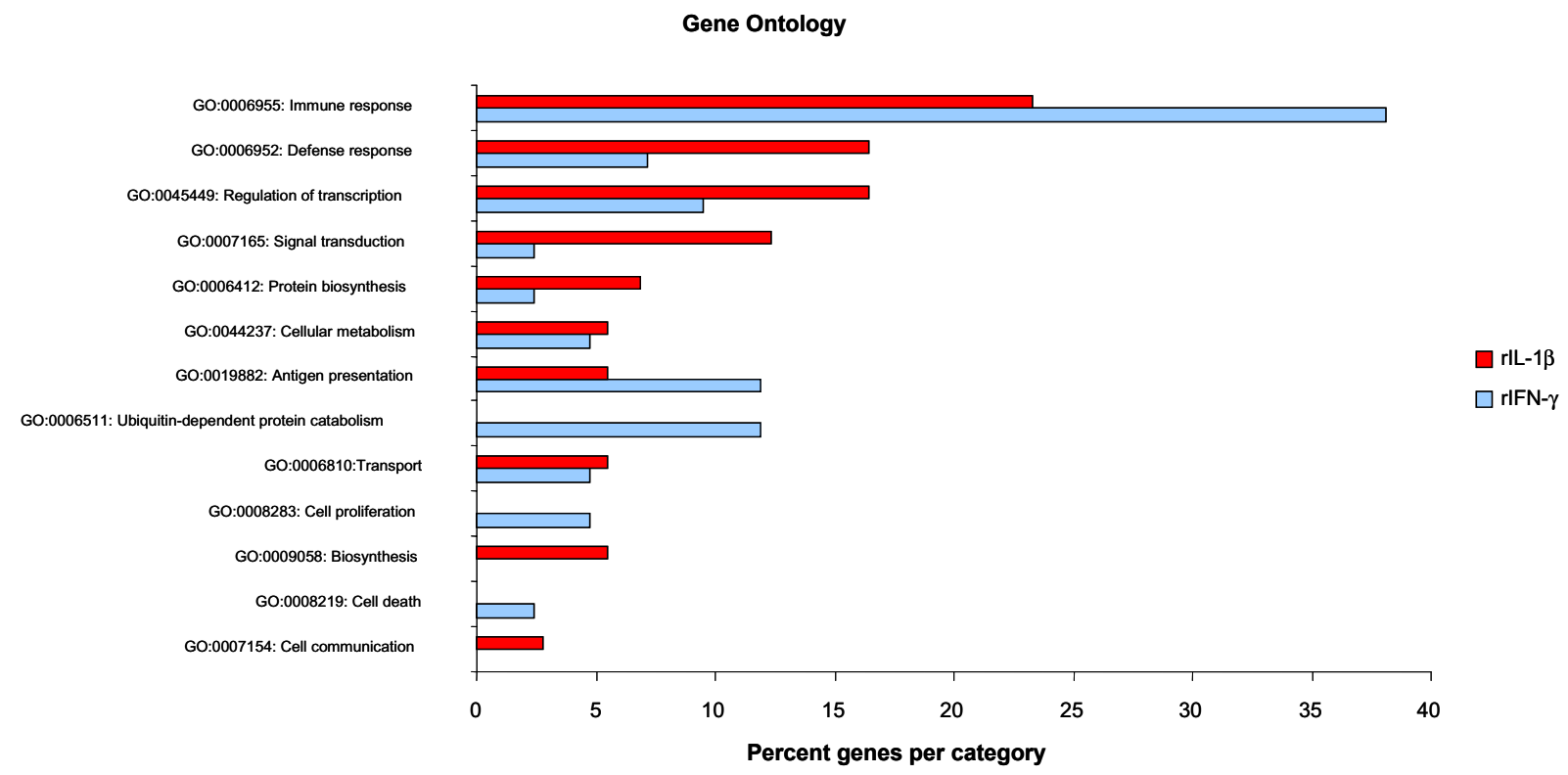

Figure I

Numbers of differentially expressed genes grouped by Gene Ontology identifier for Biological process. Summary of function of proteins encoded by genes found to be up regulated after cytokine stimulation of RTS-II cells as revealed by microarray analysis. These ontologies are only for those genes for which a functional protein could be assigned; $86 \%$ and $61 \%$ for rIFN- $\gamma$ and rIL-I $\beta$ induced genes respectively. For GO annotation high level annotations were used.

as some genes were only assigned as differentially expressed by one cytokine. The candidate gene mRNA expression was normalized to both $\beta$-actin and to ELF- $1 \alpha$, neither of which were found to vary by microarray analysis. The real time PCR results when normalized with $\beta$ actin are shown in Fig. 2. The results obtained when normalized with ELF- $1 \alpha$ are very similar and correlate significantly with the data normalized with $\beta$-actin (Pearson correlation $=0.998, \mathrm{P}<0.001)$. To compare the expression pattern obtained for the microarray and the real time PCR data the fold increase was plotted (Fig. 3) and shown to be highly correlated (Pearson correlation $=0.864, \mathrm{P}<$ 0.001 ) indicating both sets of results generally agree.

All cDNAs used in the real time PCR analysis confirmed the up regulation observed in the microarrays except one cDNA encoding a 605 ribosomal protein L30 (CA037550) which was assigned as up regulated in cells stimulated with IL-1 $\beta$ but was not found to be induced during the real time PCR assays.

\section{Temporal gene expression analysis by real time PCR}

A second stimulation on the RTS-11 cells was performed to obtain further time points $(6,24$ and 48 h post stimulation) to allow the kinetics of the transcriptional response to be monitored. Five genes were chosen for this kinetics study, the transcription factors Jun-B and IRF-1, precerebellin and hepcidin representing acute phase response genes and TAP1 as a gene involved in antigen presentation. Fig. 4 shows the expression differences obtained for these later time points. When stimulated with rIL-1 $\beta$ Jun B increases throughout the time course to a maximum of 50 fold increase at $48 \mathrm{~h}$ compared to the unstimulated control. This gene is also increased by rIFN$\gamma$ stimulation but to a much lower extent. The IRF-1 gene has a transient change in expression, being maximal at 24 $\mathrm{h}$, then decreasing by $48 \mathrm{~h}$. This response profile was also observed for the $\gamma$ IP gene following rIFN- $\gamma$ stimulation, where this gene also showed maximal expression at $24 \mathrm{~h}$ [14]. IRF- 1 is also stimulated by rIL-1 $\beta$ but to a much reduced level, and interestingly it had the same expression profile as when stimulated with IFN- $\gamma$ with highest induction at $24 \mathrm{~h}$. Temporal expression of hepcidin by rIL-1 $\beta$ stimulated cells shows maximal expression at $6 \mathrm{~h}$, with expression slowly decreasing to $48 \mathrm{~h}$, although still being highly induced (25 fold greater expression than in nonstimulated cells). The opposite is true of hepcidin mRNA expression following rIFN- $\gamma$ administration, where there is a steady increase in gene expression during the time course. One gene representing the antigen presentation pathway, TAP1 was also monitored, and also continued to increase during the time course under rIFN- $\gamma$ stimulation, 


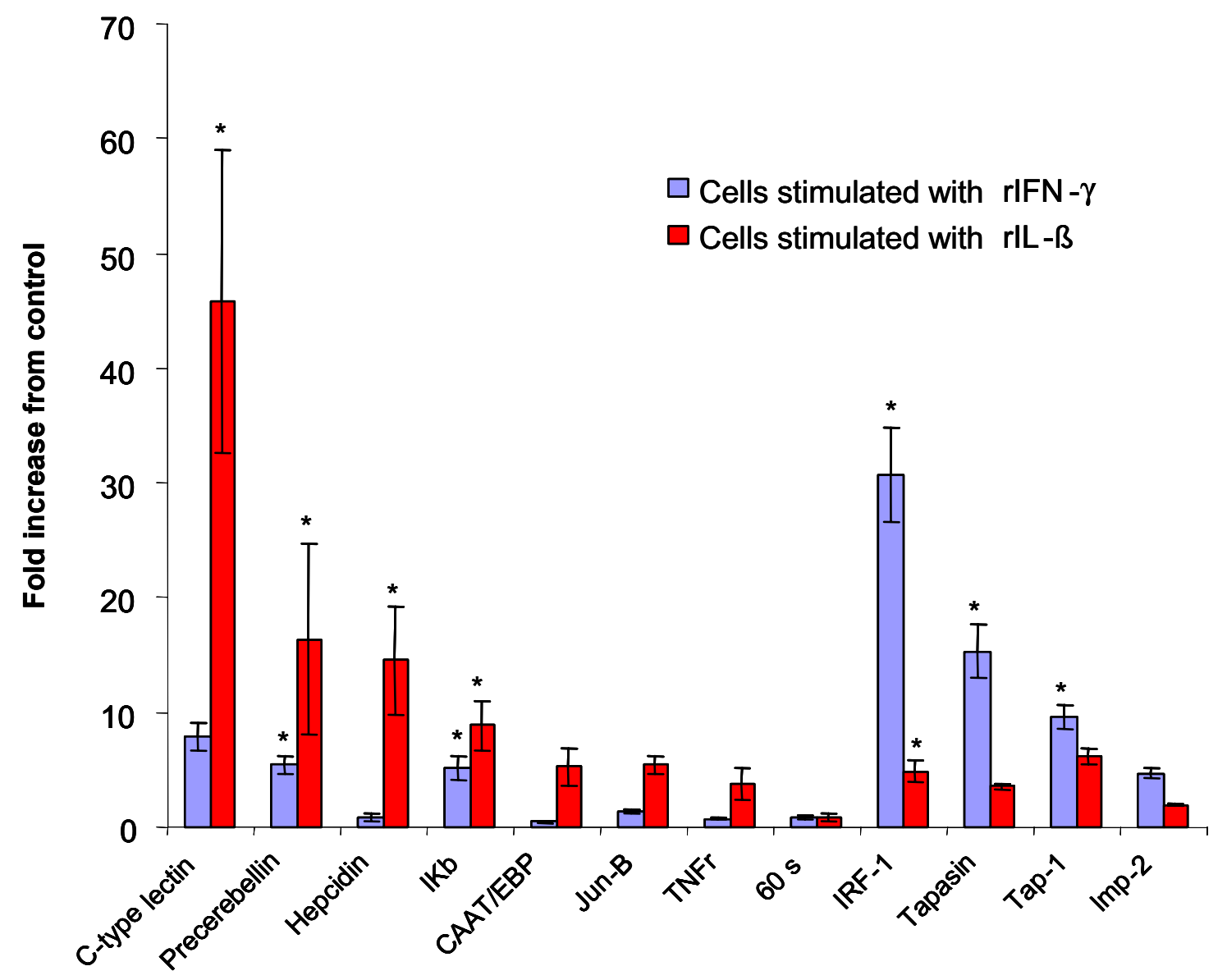

Gene Name

\section{Figure 2}

Real time PCR results on $6 \mathrm{~h}$ mRNA samples that had been used for microarray analysis. Each selected gene was examined for expression following $6 \mathrm{~h}$ stimulation with either trout rIL-I $\beta$ or trout $\mathrm{rIFN}-\gamma$. The expression of each gene was normalised to $\beta$-actin. The real time PCRs were all performed in triplicate and are shown as mean \pm SEM. (* indicates the increase in expression compared to control is significant by t test $P<0.05$ ). Genes were ordered in relation to largest fold increase induced by $\mathrm{rIL}-\mathrm{I} \beta$ or $\mathrm{rIFN}-\gamma$ with the $60 \mathrm{~S}$ ribosomal protein not showing induction by either cytokine.

suggesting an increasing capacity for $\mathrm{MCH}$ class I presentation. There was also an increase in expression in cells stimulated with the rIL- $1 \beta$ at $6 \mathrm{~h}$ as observed in the microarray, but following this no signal was detected indicating this was only a transient increase.

\section{Discussion}

In vertebrates, innate immunity provides a first line of host defense against pathogens and the signals that are needed for the activation of adaptive immunity. Activation of the endogenous inflammatory response by both IL-1 $\beta$ and IFN- $\gamma$ will give key insights to the mechanisms by which these cytokines function in fish. We hypothe- sized that stimulation with these recombinant proteins may identify genes that could help develop models for analyzing the progression of the inflammatory response in lower vertebrates. Studies with cultured cells avoids the complex host and cell type response observed using in vivo experiments and the application of DNA microarray technology is expected to reveal many of the cytokine responsive genes

Recently we have produced biologically active recombinant fish cytokines IL- $1 \beta$ and IFN- $\gamma$ from rainbow trout $[14,30]$. To further this work we have stimulated a macrophage cell line (RTS-11) with these recombinant proteins 


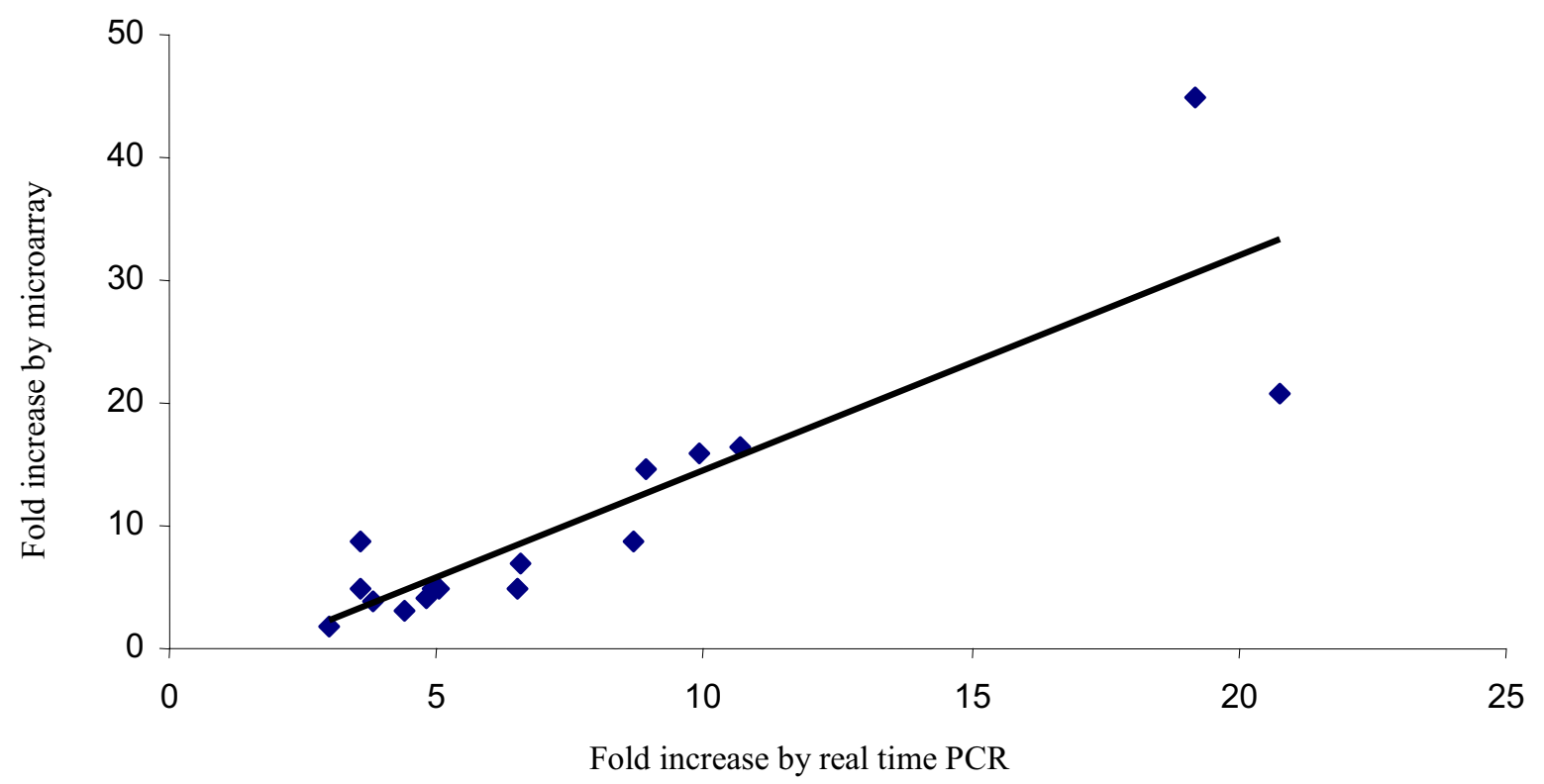

Figure 3

Analysis of the expression induction by both microarray and real time PCR. For the microarray data, the mean value was used if the gene occurred more than once on the microarray. There is a significant correlation between the values obtained by microarray and real time PCR (Pearson correlation $=0.864, \mathrm{P}<0.00 \mathrm{I}$ ).

and characterized the transcriptional response. Classically IL-1 $\beta$ is stimulated early during an infection or stimulation of cells, with 3-6 h being an optimal time for IL-1 $\beta$ to be expressed and then to induce down stream genes [55]. IFN- $\gamma$ provokes a large variety of immune responses by stimulating intracellular gene expression. In particular it is a potent activator of macrophages, and in addition to this it increases antigen presentation and attracts leukocytes to infected tissue sites, mainly through induction of gene expression of a number of factors including MHC molecules and chemokines such as $\gamma$-IP, a T cell attractant [56].

The micro array analysis performed here has demonstrated there are a variety of genes induced following stimulation with these two recombinant proteins, with a number induced by both cytokines, although the scale of induction varies. In general terms we show that trout rIL$1 \beta$ induces transcription of genes that may bias the cells towards an acute phase type of response, with key genes stimulated having this function, whilst rIFN- $\gamma$ appears to be inducing genes indicative of an adaptive Th1 response. A model diagram highlighting these key features is shown in Fig. 5. A large proportion of the genes stimulated by trout rIL-1 $\beta$ are involved in antibacterial activities or activation of antibacterial responses, with many of these genes being characterised previously as acute phase response proteins. Although the acute phase response proteins are usually found in liver, in fish they are expressed in many immune responsive tissues [20] and in this study in a macrophage cell line. Central to the coordinated response is the activation and production of nuclear transcription factors. rIL-1 $\beta$ stimulates transcription factors including Jun- $\mathrm{B}, \mathrm{C} / \mathrm{EBP}$, and $\mathrm{I} \kappa \mathrm{B}$ which transduce the signal from the cytokine IL-1 receptor to responsive genes. A key antibacterial peptide, hepcidin is strongly induced by rIL-1 $\beta$. This gene is stimulated in a variety of fish species in response to various bacterial pathogens, as seen in Atlantic salmon [20,57], winter flounder [58] and hybrid stripped bass [59], and in mammals several inflammatory cytokines including IL-1 $\beta[60]$ and IL-6 [61] can regulate hepcidin production. Probably this expression is an indirect affect of IL-1 $\beta$, through its ability to induce gene expression of transcription factors that bind to the promoter of the hepcidin gene. Both NFאB and C/EBP $\beta$ sites have been found in the promoters of mammal [62] and fish hepcidin genes $[57,63]$, and in this study it was observed that C/EBP is increased by rIL-1 $\beta$. The precise method by which bacteria are killed by hepcidin remains unclear, but may be linked to hepcidin being a negative regulator of iron metabolism [64]. It appears in fish that the key role of hepcidin is as an antimicrobial peptide, but 

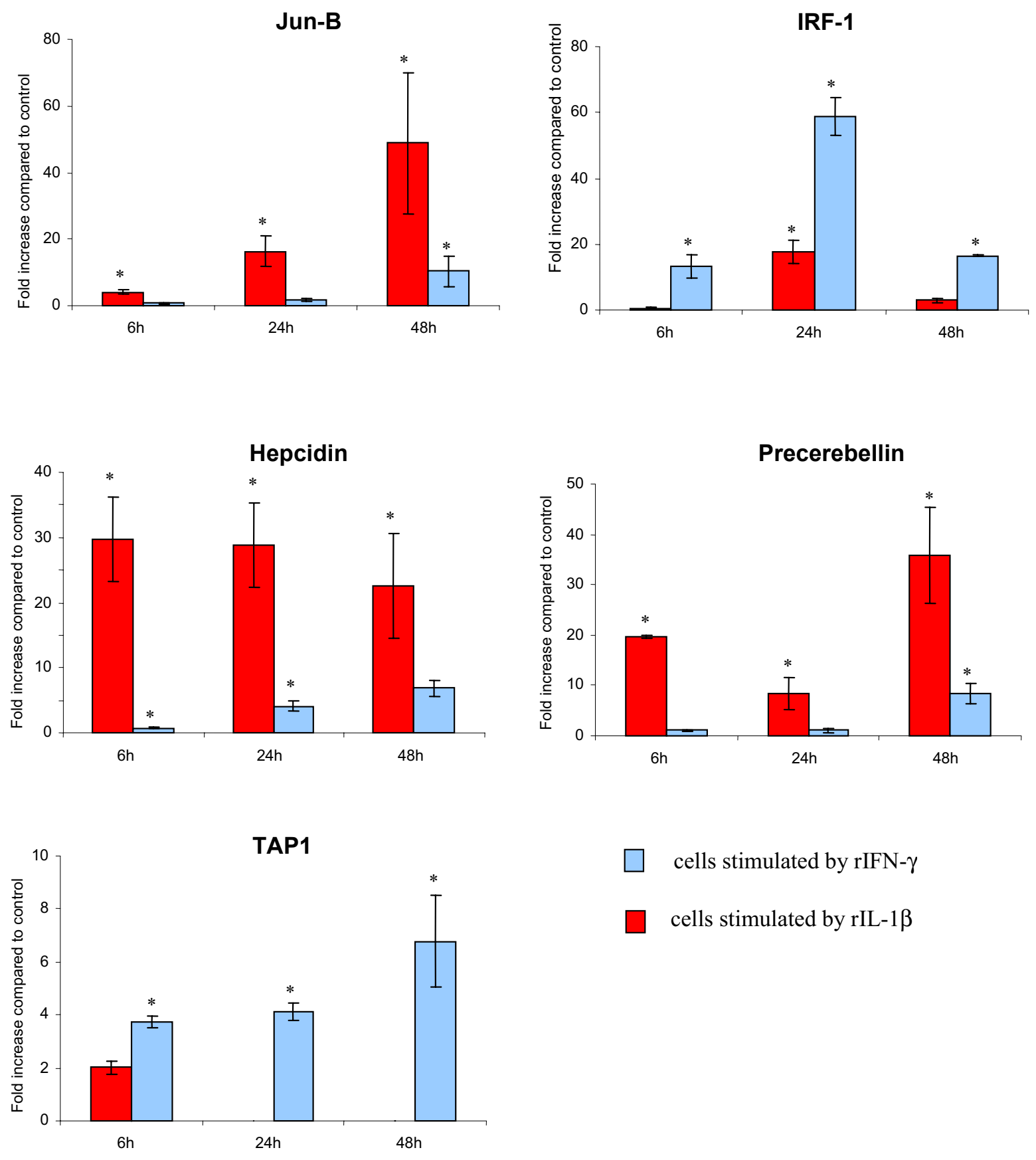

cells stimulated by rIFN- $\gamma$

cells stimulated by rIL-1 $\beta$

Figure 4

Temporal expression of genes stimulated by rIL-I $\beta$ and rIFN- $\gamma$ in RTS-I I cells. Cells were incubated for either 6 , 24 or $48 \mathrm{~h}$ with recombinant cytokine at $20 \mathrm{ngml}^{-1}$. The real time PCRs were normalized against $\beta$-actin expression. *Indicates if the expression in the stimulated cells is significantly different than the control cells by $t$-test $(P<0.05)$. 


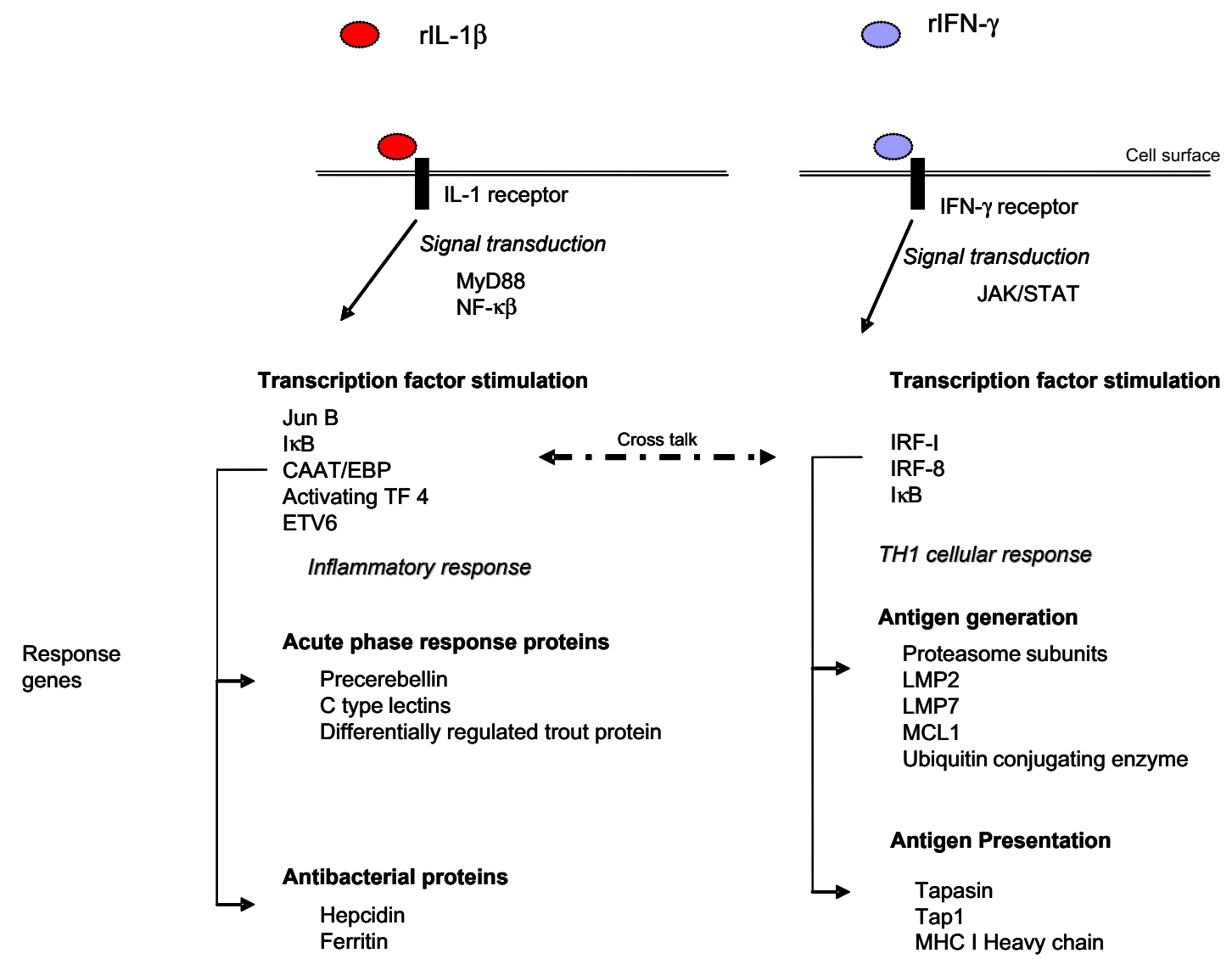

Figure 5

Proposed model for transcriptional responses in RTS I I cells. Key transcriptional differences observed following stimulation of rainbow trout RTS I I cell line with recombinant IL-I $\beta$ or IFN- $\gamma$ are shown.

through evolution it has also become an iron regulatory hormone; the extent of iron regulatory function of hepcidin in fish is still unknown [65]. A major iron regulator, ferritin (also considered an acute phase response protein) was also up regulated by rIL-1 $\beta$, and functions to prevent the proliferation of an invading bacterial pathogen. This primitive yet effective antimicrobial mechanism operates by depriving microbial organisms of their nutrients in what is commonly referred to as the iron-withholding strategy of innate immunity [66]. This up regulation of ferritin mRNA is increased following differing bacterial infections in both vertebrates and invertebrates such as shrimp [67]. In mammals this expression is regulated by pro inflammatory cytokines at both the transcriptional and translational level [68], however the mechanisms in lower vertebrates and invertebrates are yet to be determined.
Correct pathogen identification is essential in order to elicit a protective host response, which can occur through recognition of PAMPS. Lectin receptors function to bind sugar motifs on the surface of invading pathogens and in activation of complement and as such are important in the innate defence against bacterial infections. This mechanism is conserved throughout vertebrate evolution [68]. Lectin and Toll receptors have related functions, both recognising conserved products of microbial metabolism [70]. C-type lectin mRNAs are widely reported to be increased following different bacterial infections in salmonid fish such as Piscirickettsia salmonis [22], Aeromonas salmonicida [20,21,57], and by infection with Vibrio anguillarum in rainbow trout [71]. Lectins may be involved in signalling following virus infection as seen with Rhabdovirus infection [72] and can be induced by administration of the double stranded RNA poly I:C [73]. 
In this study C-type lectins were highly induced by rIL-1 $\beta$ and to a lesser extent by rIFN- $\gamma$, indicating there is an increase in production during the inflammatory response to increase recognition of pathogens and activate the lectin pathway of complement. Evidence is growing that lectin like receptors can synergise or antagonise toll like receptor signalling which may occur via the immuno receptor tyrosine based activation motif (ITAM) found in the TLR2 receptor [74]. In common with other acute phase response proteins, $\mathrm{C}$-type lectins have transcription factor binding sites for NFKB, NF/IL-6 and C/EBP [75]. A galactose binding lectin, galectin, stimulated in this study by rIFN- $\gamma$ is described as an eosinophil chemoattractant produced by activated T lymphocytes. Endothelium cells from humans suffering from inflammatory disease express galectin-9, known to be stimulated by IFN- $\gamma$ and as such, galectin may help regulate interactions between the vascular wall and eosinophils during the inflammatory response [76].

A factors involved in cell differentiation and commitment is a myristoylated alanine-rich C kinase (MARCKS) found increased by IL-1 $\beta$. MARCKS also has a role in macrophage and neutrophil motility and functions to direct cells towards proliferation [77]. In addition ETV-6 is a transcription factor (Ets factor) increased by rIL-1 $\beta$ that results in differentiation and commitment of a cell to a specific fate. Ets factors play a critical role in the regulation of genes involved in tissue-development, differentiation, cell cycle control, and cell proliferation as both transcriptional enhancers or repressors, some of which are located in the MHC cluster [78]. This could indicate rIL-1 $\beta$ is initiating the reprogramming of the RTS-11 cells.

IFN- $\gamma$ exerts its effect via a signalling cascade through the Jak/Stat pathway [79] which stimulates interferon response factors which either enhance or inhibit expression of interferon responsive genes. Two interferon response factors (IRF) 1 and 8 are dramatically up regulated by rIFN- $\gamma$ stimulation demonstrating the cells are responding to the IFN- $\gamma$ in a predictable manner. A major group of genes that are stimulated by IFN- $\gamma$ are those involved in MHC class I antigen presentation [37]. MHC class I molecules present endogenously synthesized peptides including virus peptides following viral infection. Upon stimulation with IFN- $\gamma$ many of the genes in this pathway are transcriptionally stimulated and the cell can then increase the rate at which these peptides are presented on the cell surface for subsequent recognition by cytotoxic $\mathrm{T}$ cells [80]. This pathway involves proteins being targeted by ubiquitination and directed to the proteasome which digests the protein into peptides that are bound to MHC class I and $\beta 2$ microglobulin before being transported to the cell surface. Once the proteins have been cleaved into peptides by the proteasome they are transported to the endoplasmic reticulum and the TAP and tapasin molecules bind the peptides to the MHC class I heavy chain and in the presence of $\beta 2$ microglobulin form the mature MHC molecule that is presented on the cell surface. Three subunits from the proteasome LMP2, LMP7 and MELC1 as well as TAP 1 and tapasin mRNAs were significantly increased in expression in the IFN- $\gamma$ stimulated cells. $\beta 2$ microglobulin was also increased but was not included in the results Table 2 as it was less that 2 fold increased. These results clearly indicate the RTS- 11 cells are being primed by the recombinant IFN $-\gamma$ to follow a Th1 pathway to stimulate an adaptive immune response.

There are a number of genes that are stimulated by both rIFN- $\gamma$ and rIL-1 $\beta$. These include I $\mathrm{B}$ which is involved in

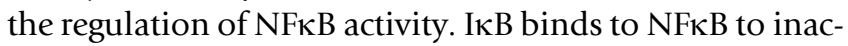
tivate it, but during activation by cytokine stimuli the $I \kappa B$ is phosphorylated by I $\kappa \mathrm{B}$ kinase (IKK) and subsequently unbiquitinated and destroyed by the proteasome [81]. Several genes encoding the proteins involved in antigen presentation are also transcriptionally increased by rIL- $\beta$, but at a lower level than with rIFN- $\gamma$ stimulation, indicating that this is not a major function of IL1- $\beta$. rIL-1 $\beta$ also increased IRF-1 expression but to a much lower degree than found with rIFN- $\gamma$ stimulation. Together these results demonstrate there is cross talk between the regulation of genes controlled by these two cytokines, with a possible co stimulatory role via IL-12 mediated induction of IFN- $\gamma$ [82] and this may be the mechanism by which the cytokines stimulate the same subset of genes. Three mRNAs are stimulated by rIL-1 $\beta$ for which the precise functions remain unknown. These are precerebellin [71], "Differentially regulated trout protein" [71], and "Immune response protein 1" [22], the latter is stimulated by both rIL-1 $\beta$ and rIFN- $\gamma$. These genes may be regarded as markers of a major immune function responding in a positive manner to inflammatory stimuli and are likely to be regulated in a similar manor to acute phase response proteins.

The expression difference of ten mRNAs were chosen for extended analysis by real time PCR to determine if the difference found by microarray analysis could be confirmed by real time PCR. These genes showed exclusively or preferentially increased expression by one or other of the cytokines and represented the major functional groups found to be stimulated by the microarray analysis. Hepcidin, C type lectin and precerebellin were chosen to represent acute phase response proteins and antibacterial peptides. Genes encoding transcription factors JunB, C/ EBP, IкB and IRF-1 were selected as these may be central to progression of the cells response and genes representing antigen presentation included TAP1, LMP2 and tapasin. Two further genes, a tumor necrosis factor (TNF) 
receptor which represents a proinflammatory cytokine receptor and a 60s ribosomal protein mRNA as an indicator of cellular protein translation, were also used. The expression profile from the microarrays correlated well with the results obtained from the real time PCR indicating robust analysis of the microarray. The highly significant correlation when the real time PCRs were normalised to either $\beta$-actin or ELF- $1 \alpha$ shows that both these control genes are suitable for normalizing the IL- $1 \beta$ and IFN- $\gamma$ responsive genes which are changed in expression.

The real time PCRs investigating the temporal expression revealed that there is a limited amount of co regulation of genes responding to both rIL-1 $\beta$ and IFN- $\gamma$ as discussed earlier. Interestingly, several of the genes respond to the stimulants with different kinetics. The antibacterial peptide hepcidin and precerebellin are expressed at very low levels $6 \mathrm{~h}$ after IFN- $\gamma$ stimulation, but the expression continues to rise until $48 \mathrm{~h}$, this could be as a result of the IFN- $\gamma$ stimulating genes which in turn are activating NFKB signal transduction pathway and causing this later expression. Although this is a much lower fold difference than seen with rIL-1 $\beta$ it may indicate the acute phase response is retarded when cells are stimulated with rIFN- $\gamma$ compared to rIL-1 $\beta$. Conversely TAP 1 , which may indicate a shift towards adaptive immunity, increases in expression throughout the time course after IFN- $\gamma$ stimulation. An increase is observed at $6 \mathrm{~h}$ after IL- $1 \beta$ stimulation but then no expression difference is observed at 24 and $48 \mathrm{~h}$ indicating this pathway is not increased over time by IL-1 $\beta$. There may be an autocrine effect following the stimulation with IL-1 $\beta$ that affects the expression of precerebellin, since the gene expression decreases at $24 \mathrm{~h}$ and then rises again at $48 \mathrm{~h}$ relative to the control. This may reflect increased IL- $1 \beta$ expression by the RTS 11 cells themselves that causes a secondary enhanced response at $48 \mathrm{~h}$.

At the most basic level all vertebrates need to respond in the correct manner to pathogens, with control of gene expression during the response being central for successful elimination of the pathogen. Throughout the vertebrates there are common sets of genes which are activated during this response although many pathogens attempt to disrupt this response, often by altering the effect and profile of cytokines. To remove pathogen and host effects we have used a cell line to directly study the effect of cytokines on the transcriptional response, and our results obtained here can be directly compared to transcriptome changes observed in mammalian cells following cytokine stimulation. IL-1 $\beta$ stimulation increases transcription for genes encoding proteins associated with the antipathogen response, proliferation and inflammation, via the NFKB signal transduction route $[82,83]$. For IFN- $\gamma$ stimulation in various mammalian cells, gene sets similar to those found in fish show modulated expression, with genes encoding proteins related to antigen presentation and immunomodulatory activities stimulated in both macrophages $[47,84]$ and astrocytes [85]. From this we can speculate that the general response to these key cytokines is conserved throughout vertebrates although there can be variation in response depending on factors such as cell type and incubation time [43].

\section{Conclusion}

In conclusion, these results further our understanding of gene expression alterations induced by specific cytokines in salmonid cells. This is the first time that an in depth study has been performed using recombinant cytokine molecules for transcriptional profiling in a lower vertebrate. We clearly demonstrate that the rIL-1 $\beta$ enhances the expression of molecules involved in the acute phase response and innate immune mechanisms, whereas a major shift in gene expression towards the adaptive response and MHC class I antigen presentation is seen when using rIFN- $\gamma$. Gene ontology confirmed that the major groups of genes altered in expression were related to the immune response.

\section{Methods \\ Cell culture}

The rainbow trout macrophage cell line RTS-11 [49] was maintained in L15 medium containing 30\% FCS (Labtech International $)$ and antibiotics $\left(100 \mu \mathrm{g} \mathrm{ml}^{-1}\right.$ penicillin and $100 \mathrm{U} \mathrm{ml}^{-1}$ streptomycin, $\mathrm{P} / \mathrm{S}$ ) at $20^{\circ} \mathrm{C}$. Cells were passaged to fresh flasks at $80 \%$ confluence and cultured for 2 days before stimulation with the recombinant proteins for $6 \mathrm{~h}$ at a concentration of $20 \mathrm{ng} \mathrm{ml}^{-1}$. This time point and concentration was chosen on evidence from previous experiments, with rIL-1 $\beta$ stimulated genes including cycloxygenase- 2 and IL- $1 \beta$ being induced maximally at 6 $\mathrm{h}$ [30] and rIFN- $\gamma$ also showing good stimulation between 4 and $8 \mathrm{~h}$ of genes including guanylate-binding protein [86] and $\gamma$-IP being maximally stimulated at $6 \mathrm{~h} \mathrm{[13].}$ Later timings also have the potential issue of indirect effects caused by induced gene products. For both recombinant cytokines the response of stimulated genes plateaus with a concentration of between 10 and $20 \mathrm{ng} \mathrm{ml}^{-1}$, with higher concentrations not giving significantly higher transcription levels $[14,30,86]$. Cells were cultured in 80 $\mathrm{cm}^{2}$ flasks for the microarray experiment but for the time course experiment cells were cultured in $25 \mathrm{~cm}^{2}$ flasks for 6,24 or 48 h.

\section{RNA isolation}

The RTS-11 cell line is a mixture of adherent and non adherent cells. The non adherent cells were pelleted by centrifugation at $600 \mathrm{~g}$ for $5 \mathrm{~min}$. These pelleted cells were lysed and combined with the adherent cells. Total RNA was extracted using the RNA STAT60 reagent (AMS Biotechnology) according to the manufacturer's instructions. 
RNA was resuspended in DEPC treated water and the concentration and quality of the RNA was determined by spectrophotometry and using an Agilent Bioanalyser 2100 (for RNA integrity).

\section{Microarray hybridization}

The microarray used in this study was constructed from cDNAs selected from 18 high complexity salmonid cDNA libraries and consisted of 16,006 cDNA features [50]. The majority of cDNAs selected for the chip came from a normalized mixed tissue library (spleen, kidney and brain). The full list of genes contained on this array can be found at http://web.uvic.ca/cbr/grasp/GAL 16006.gal. For array hybridizations triplicate RNA samples were used that were obtained from RTS-11 cells stimulated with either trout rIL-1 $\beta$ or rIFN- $\gamma$, as described earlier or unstimulated control cells. Next, $20 \mu \mathrm{g}$ total RNA was primed with oligo dT primer and reverse transcribed in the presence of amino allyl modified dUTP following the manufacturer's instructions (Post Labelling Kit, Amersham Biosciences). Following reverse transcription, RNA template was removed by sodium hydroxide treatment and unincorporated nucleotides removed using a spin column (GFX spin Column, Amersham Biosciences). The fluorescent label, either $\mathrm{Cy} 3$ or Cy5 was added to the purified cDNA in the dark in a volume of $30 \mu \mathrm{l}$ and the labelled cDNA purified from free dye on a GFX column. For the dye swap experiments the cDNA was split to two equal aliquots before the dye was coupled to the cDNA. Six slides were used in total per experiment, i.e. for each recombinant cytokine. Prior to hybridization $1.5 \mu \mathrm{ld}(\mathrm{A})_{80}\left(1 \mathrm{mg} \mathrm{ml}^{-1}\right), 110 \mu \mathrm{l}$ formamide, $55 \mu$ hybridization buffer (Amersham Biosciences) and water was added to give a final volume of $220 \mu$ l. The cDNA was heated to $95^{\circ} \mathrm{C}$ for 2 min before being added to the hybridization chamber. The hybridization was performed for $16 \mathrm{~h}$ at $42^{\circ} \mathrm{C}$ on an Amersham Lucidea hybridization station. Prior to hybridization slides were pretreated by heating in water at $95^{\circ} \mathrm{C}$ for $5 \mathrm{~min}$, then washed with isopropanol and air dried. Post hybridization washes (10 min each) were as follows: $1 \times$ SSC $\left(45^{\circ} \mathrm{C}\right), 1 \times \mathrm{SSC}+0.2 \% \mathrm{SDS}\left(45^{\circ} \mathrm{C}\right), 0.1 \times \mathrm{SSC}+0.2 \% \mathrm{SDS}$ $\left(20^{\circ} \mathrm{C}\right)$. Slides were then dried before being scanned.

\section{Microarray image analysis}

After hybridization and washing, the slides were scanned on an Axon 4200A scanner (Axon Instruments) at a resolution of $10 \mu \mathrm{m}$ and saved as *.TIF files. The detected flourescence was adjusted by altering the photo multiplying tube (PMT), this ranged from 700-820 (arbitrary units) to give an intensity ratio of the slides of approxi-

Table I: Primer sequences used for gene expression analysis by real time PCR. Amplification was detected by Sybr Green using an Opticon real time PCR machine (BioRad).

\begin{tabular}{|c|c|c|c|c|c|}
\hline Gene & Accession number & Short name & Sequence & Annealing temp used & Product size \\
\hline \multirow[t]{2}{*}{ HEPCIDIN } & BX868476 & ExtIFI & TGCAGTGGTACTCGTCCTTG & 58 & 167 \\
\hline & & ExtIRI & GACGCTTGAACCTGAAATGCTCC & & \\
\hline \multirow[t]{2}{*}{ IRF-I } & AF332147 & IRF-I FI & CCGCTGTGCAATGAACT & 60 & 285 \\
\hline & & IRF-I RI & AGGCTGTCTGTGCTGTCTACTAT & & \\
\hline \multirow[t]{2}{*}{ C-TYPE LECTIN } & DVI91936 & Ext2tFI & TCTCCTGTCCCATTTTGCTT & 58 & 238 \\
\hline & & Ext2RI & GATCCGCCATCCACATATTC & & \\
\hline \multirow[t]{2}{*}{ PRECEREBELLIN } & AFI92969.2 & Ext3FI & GCCTTCTCCGCTTCCTTTAT & 58 & 185 \\
\hline & & Ext3RI & TTCCCAACATTGCAAGTGAA & & \\
\hline \multirow[t]{2}{*}{ IN NFKbeta } & OMY317969 & Exts4FI & GAAGCCACAGAACATGCTGA & 58 & 242 \\
\hline & & Exts4RI & TGGGTGATCACACTGAAGGA & & \\
\hline \multirow[t]{2}{*}{ JUN-B } & CF752495.I & Ext5FI & TACTGCACTGTTGGGACAGC & 58 & 167 \\
\hline & & Ext5RI & CAGAATGCCCCGAGTGTTAT & & \\
\hline \multirow[t]{2}{*}{ LMP2 } & AFII 2117.1 & Ext6FI & AAGTTCGTTCAGCTGCCACT & 58 & 234 \\
\hline & & Ext6RI & GTTGGCAGTCCTCTTTGCTC & & \\
\hline \multirow[t]{2}{*}{ TAPI } & AFII5536 & Ext7FI & CCATGAGTCGCATACACACC & 58 & 188 \\
\hline & & Ext7RI & AGTGACCCGCATGAAGTACC & & \\
\hline \multirow[t]{2}{*}{$60 \mathrm{~S}$ rp L30 } & CA037550 & Ext9FI & GGGATACAAGCAGTCCCAGA & 58 & 211 \\
\hline & & Ext9RI & GGGTCGATGATAGCCAGTGT & & \\
\hline \multirow[t]{2}{*}{ CCAAT/EBP } & AYI446II.I & ExstIOFI & CAGCGGGTGTTAAGATCCAT & 58 & 200 \\
\hline & & ExstIORI & GCAGCAGGAGGATCCAAGTA & & \\
\hline \multirow[t]{2}{*}{ TNF rec } & OMY5I7804 & ExtlIFI & CACCGACTGTGGCAAGTCTA & 58 & 227 \\
\hline & & Extl|RI & GGGTCACAGGTAGGCAGTGT & & \\
\hline \multirow[t]{2}{*}{ TAPASIN } & DQ092322 & Ext $\mid 2 \mathrm{FI}$ & GCACGGTGTACTTGCCCTAT & 58 & 188 \\
\hline & & Ext|2RI & AGGCCCTGTTAACTCCCAGT & & \\
\hline \multirow[t]{2}{*}{$\beta$-ACTIN } & $\mathrm{AFO}|2| 25$ & RTBAEF & CCAGGCATCAGGGAGTGA & 60 & 283 \\
\hline & & RTBAER & GTACATGGCAGGGGTGTTGA & & \\
\hline \multirow[t]{2}{*}{ ELF-I $\alpha$} & AF321836.I & EFIAEF & CAAGGATATCCGTCGTGGCA & 60 & 317 \\
\hline & & EFIaER & ACAGCGAAACGACCAAGAGG & & \\
\hline
\end{tabular}


Table 2: cDNAs identified as differentially regulated by microarray analysis. Clone ID ${ }^{\prime}$ is the accession number of the cDNA feature on the microarray, when more than one cDNA feature was the same sequence the accession number for the feature with the highest fold difference is given, the number in brackets indicates the number of features identical and used in analysis. Identity ${ }^{2}$ is the functional protein assigned to the cDNA feature, Accession ${ }^{3}$ number relates to the identify of the protein. *indicates cDNA features where protein function is determined from NCBI UniGene as described in the text. Mean is the mean fold difference between the stimulated and non stimulated control cells.

\begin{tabular}{|c|c|c|c|c|c|}
\hline Clone IDI & Identity ${ }^{2}$ & Accession $^{3}$ & Gene Ontology Identifier & Mean & SEM \\
\hline \multicolumn{6}{|c|}{$U_{p}$ regulated by rIFN- $\gamma$} \\
\hline CA063565(2) & Interferon regulatory factor I & AAM77843 & GO:0003700: transcription factor activity & 12.1 & 4.9 \\
\hline CA062585(2) & Tapasin & ABE27285 & GO:00 I9882: antigen presentation & 11.4 & 3.5 \\
\hline CA063956 & Complement $\mathrm{Clq}$ & XP_544507.2 & GO:0006955: immune response & 11.4 & 2.7 \\
\hline CB505764 & $\mathrm{Clq}$-like adipose specific protein & AAM7370I & GO:0006955: immune response & 10.6 & 5.8 \\
\hline CA062838*(2) & Acyl-coenzyme A-binding protein & AJ632152 & GO:0006810: transport & 10.3 & 1.4 \\
\hline CA051393* & $\begin{array}{l}\text { Interferon consensus sequence binding protein } \\
\text { (IRF-8) }\end{array}$ & NP_990747.I & GO:0003700: transcription factor activity & 10.0 & 4.7 \\
\hline CA062698* & Ssa. 15825 & & $\mathrm{~N} / \mathrm{A}$ & 9.6 & 5.0 \\
\hline CB506130 & Proteasome subunit beta type I-A $20 \mathrm{~S}$ & 009061 & $\begin{array}{l}\text { GO:00065 I I: ubiquitin-dependent protein } \\
\text { catabolism }\end{array}$ & 9.2 & 6.2 \\
\hline CA062737(3) & Low molecular mass protein 7 & P28063 & GO:0006955: immune response & 8.8 & 3.3 \\
\hline CA052500 & TAP I & Q9JJ59 & GO:0019882: antigen presentation & 8.7 & $\mathrm{I} .4$ \\
\hline CA056108(2) & C-type lectin 2-1 & Q9IZW7 & GO:0006955: immune response & 8.5 & 3.8 \\
\hline CA055080 & Core histone macroH2A $2.2 ; \mathrm{H} 2 \mathrm{~A}$ histone family & AAH76893 & GO:0044237 : cellular metabolism & 7.6 & 4.3 \\
\hline CB5I6220(2) & Inhibitor of nuclear factor kappa B alpha & Q9ZIE3 & GO:0006955: immune response & 7.3 & 3.9 \\
\hline CA057910* & Programmed cell death I ligand I & XP_4248II.I & GO:0008219: cell death & 6.8 & 1.5 \\
\hline CA05I372(2) & Low molecular mass protein 2 & Q60692 & GO:0006955: immune response & 6.5 & 2.5 \\
\hline CB5II048 & VHSV-induced C-lectin-like protein & AY572832 & GO:0006955: immune response & 6.1 & 3.0 \\
\hline CA063009*(2) & Ssa.6457 & & $\mathrm{N} / \mathrm{A}$ & 6.0 & 1.7 \\
\hline CA0527I7* & Fc receptor-like 4 & XP_547521.2 & $\mathrm{N} / \mathrm{A}$ & 5.7 & 2.0 \\
\hline CA050I49 & IMMUNE-RESPONSIVE PROTEIN I & XP_5426I5 & $\mathrm{N} / \mathrm{A}$ & 4.1 & 1.6 \\
\hline CA05097I & Proteasome subunit alpha type 6 & Q9QQUM9 & $\begin{array}{l}\text { GO:00065 I I: ubiquitin-dependent protein } \\
\text { catabolism }\end{array}$ & 3.8 & 1.5 \\
\hline CA063863* & Similar to interferon regulatory factor I & NP_002189.I & GO:0003700: transcription factor activity & 3.6 & 0.4 \\
\hline CA052613 & Ubiquitin conjugating enzyme & XP_517968 & $\begin{array}{l}\text { GO:00065 I I: ubiquitin-dependent protein } \\
\text { catabolism }\end{array}$ & 3.6 & 0.6 \\
\hline CB500I08 & Ribosomal protein L35 & AAM34649 & GO:00064 12: protein biosynthesis & 3.4 & 0.8 \\
\hline CA044026(2) & MHC class I & L07605 & GO:0019882: antigen presentation & 3.4 & 0.4 \\
\hline CA052774 & Protein phosphatase 2 & P627I5 & GO:0044237 : cellular metabolism & 3.0 & 0.5 \\
\hline CB5II680(2) & Lysozyme & PI7897 & GO:0006952: defense response & 3.0 & 0.3 \\
\hline CA055I86 & MECLI & P70195 & $\begin{array}{l}\text { GO:00065 I I: ubiquitin-dependent protein } \\
\text { catabolism }\end{array}$ & 2.7 & 0.5 \\
\hline CB493732 & Proteasome subunit beta type 7 & NP_989728.I & $\begin{array}{l}\text { GO:00065 I I: ubiquitin-dependent protein } \\
\text { catabolism }\end{array}$ & 2.7 & 0.7 \\
\hline CA044982 & HESI & Q9DI72 & $N / A$ & 2.6 & 0.7 \\
\hline CB496534(3) & Ferritin & P09528 & GO:0006955: immune response & 2.3 & 0.1 \\
\hline CA05739I(2) & Granulin & $X P \_537620.2$ & GO:0008283: cell proliferation & 2.2 & 0.4 \\
\hline CA060176 & Galectin like protein & 008573 & GO:0006952: defense response & 2.2 & 0.3 \\
\hline CA06002I & Unknown & & N/A & 2.2 & 0.2 \\
\hline CA046740 & Sequestosome I; oxidative stress induced & NP_035I48 & GO:0007I65: signal transduction & 2.1 & 0.1 \\
\hline \multicolumn{6}{|c|}{ Down regulated by rIFN- $\gamma$} \\
\hline CA057408 & Annexin A2 & P07356 & $\begin{array}{l}\text { GO:00508I9 : negative regulation of } \\
\text { coagulation }\end{array}$ & 3.0 & 0.9 \\
\hline CB492780(2) & Id2 protein & P4II36 & GO:0045449: regulation of transcription & 2.9 & 0.4 \\
\hline CA040487* & Ssa. 17039 & & $\mathrm{~N} / \mathrm{A}$ & 2.4 & 0.2 \\
\hline CK990422* & Ssa.2967 & & $N / A$ & 2.3 & 0.4 \\
\hline CA769647* & Ssa.3973 & & $N / A$ & 2.3 & 0.2 \\
\hline CB509992 & I8S ribosomal RNA gene, partial sequence & AY856868 & $N / A$ & 2.1 & 0.1 \\
\hline CB491705 & similar to PREDICTED: similar to ORF2 & XP_425603.I & $\mathrm{N} / \mathrm{A}$ & 2.1 & 0.4 \\
\hline CB489453 & Hypothetical protein 2 & $X P_{-} 417016$ & $\mathrm{~N} / \mathrm{A}$ & 1.9 & 0.1 \\
\hline
\end{tabular}


Table 2: cDNAs identified as differentially regulated by microarray analysis. Clone ID ${ }^{\prime}$ is the accession number of the cDNA feature on the microarray, when more than one cDNA feature was the same sequence the accession number for the feature with the highest fold difference is given, the number in brackets indicates the number of features identical and used in analysis. Identity ${ }^{2}$ is the functional protein assigned to the cDNA feature, Accession ${ }^{3}$ number relates to the identify of the protein. *indicates cDNA features where protein function is determined from NCBI UniGene as described in the text. Mean is the mean fold difference between the stimulated and non stimulated control cells. (Continued)

\begin{tabular}{|c|c|c|c|c|c|}
\hline CA050I49 & IMMUNE-RESPONSIVE PROTEIN I & XP_542615 & N/A & 27.7 & 10.4 \\
\hline CB5II 1048 & VHSV-induced C-lectin-like & AY572832 & GO:0006955: immune response & 23.2 & 10.8 \\
\hline CA06127I & UNKNOWN & & N/A & 21.2 & 9.8 \\
\hline CK991068(3) & Hepcidin & AAO85553 & GO:0006952: defense response & 21.2 & 5.0 \\
\hline CA055080 & Core histone macroH2A $2.2 ; \mathrm{H} 2 \mathrm{~A}$ histone family & AAH76893 & GO:0044237: cellular metabolism & 20.7 & 2.2 \\
\hline CA037550 & $60 S$ ribosomal protein $L 30$ & P62889 & GO:00064I2: protein biosynthesis & 19.0 & 8.5 \\
\hline CB496842(3) & C-type lectin & Q9IZW7 & GO:0006955: immune response & 18.4 & 4.1 \\
\hline CA054326 & Taxl binding protein I & NP_0060I5.4 & GO:0007I65: signal transduction & 15.9 & 10.5 \\
\hline CA063656 & Cyclin LI & AY606031 & N/A & 14.2 & 10.4 \\
\hline CB5III230 & TAP2 & AF002180 & GO:0019882: antigen presentation & 13.0 & 6.4 \\
\hline CK990725 & RhoE & P61588 & GO:0007I65: signal transduction & 12.5 & 5.6 \\
\hline CB504496(3) & Differentially regulated trout protein I & AAG30030 & GO:0006955: immune response & 12.3 & 4.5 \\
\hline CA063738* & $\begin{array}{l}\text { Nuclear factor of } k \text { light polypeptide gene } \\
\text { enhancer (p49/p } 00)\end{array}$ & NP_989744. & GO:0007165: signal transduction & 12.2 & 2.9 \\
\hline CB498I52* & Similar to MARCKS-like I & NP_075385.I & GO:00055 I6: calmodulin binding & 12.2 & 3.2 \\
\hline CK990269* & Connexin 31 & NP_990262.I & GO:0007I54: cell communication & 12.1 & 2.4 \\
\hline CB516988* & $\begin{array}{l}\text { PREDICTED: similar to heparan sulfate } \\
\text { proteoglycan }\end{array}$ & $X P_{-}$417362.I & GO:0006917: induction of apoptosis & 12.1 & 4.4 \\
\hline CB5I25I6* & Ssa. 2559 & & $N / A$ & 12.1 & 9.0 \\
\hline CB516929* & Ssa. 5205 & & N/A & 12.0 & 4.7 \\
\hline CA06042I(2) & CD83 & AAP939I2 & GO:0006952: defense response & 11.5 & 4.8 \\
\hline CB5I43I3 & Delta I & Q6|483 & GO:0007I54: cell communication & II.I & 7.2 \\
\hline CA063097* & Ssa.6200 & & $\mathrm{N} / \mathrm{A}$ & 11.1 & 3.6 \\
\hline CB5IIII58(2) & Precerebellin-like protein & AAF04305 & GO:0006952: defense response & 10.7 & 5.3 \\
\hline CA041210 & MARCKS-like protein & P28667 & GO:00055 I6: calmodulin binding & 9.8 & 1.7 \\
\hline CA059788(3) & Inhibitor of nuclear factor kappa B alpha & AAH62524 & GO:0006955: immune response & 9.6 & 2.6 \\
\hline CA044647* & Ssa.3390 & & N/A & 9.6 & 0.9 \\
\hline CA060755*(2) & Ssa.2872 & & $N / A$ & 9.4 & 2.3 \\
\hline CA051323* & Ssa.6734 & & N/A & 9.3 & 5.0 \\
\hline CA053062 (3) & 5-aminolevulinic acid synthase & Q8VC19 & GO:0009058: biosynthesis & 8.3 & 2.6 \\
\hline CA06I25I & RAS-related $\mathrm{C} 3$ botulinum substrate 2 & Q05।44 & GO:0006952: defense response & 8.2 & 4.6 \\
\hline CB507662* & Ssa.383 & & N/A & 8.1 & 0.4 \\
\hline CB501098* & Ssa.394I & & N/A & 7.9 & 4.4 \\
\hline CA058223 & Guanylate binding protein 4 & Q015I4 & GO:0006955: immune response & 7.8 & 2.8 \\
\hline CB5I5854* & $\begin{array}{l}\text { Similar to tumor necrosis factor, alpha-induced } \\
\text { protein } 2\end{array}$ & NP_006282.2 & GO:0006952: defense response & 7.8 & 1.1 \\
\hline CA052773 & Arginyl-tRNA synthetase & Q9D019 & GO:0009058: biosynthesis & 7.2 & 4.5 \\
\hline CA050427*(3) & Ssa9019 & & $\mathrm{N} / \mathrm{A}$ & 7.2 & 1.6 \\
\hline CB498855(2) & 6-phosphofructo-2-kinase & P70265 & GO:0044237: cellular metabolism & 7.0 & 1.2 \\
\hline CA046850 & DEAD (Asp-Glu-Ala-Asp) box polypeptide 5 & $\mathrm{PI} 7844$ & GO:0016049: cell growth & 6.8 & 3.7 \\
\hline CA0567I5(3) & Transcription factor JUN-B & P09450 & GO:0045449: regulation of transcription & 6.5 & 0.7 \\
\hline CA063635* & Ssa.5016 & & N/A & 6.5 & 3.4 \\
\hline CB5I4I04 & $\begin{array}{l}\text { Adipophilin (Adipose differentiation-related } \\
\text { protein) }\end{array}$ & P43883 & GO:00068I0: transport & 6.3 & 0.7 \\
\hline CA038364 & $\begin{array}{l}\text { Similar to ubiquinol-cytochrome c reductase } \\
\text { complex }\end{array}$ & P00I30 & GO:0044237: cellular metabolism & 6.2 & 1.6 \\
\hline CA054II4* & Ssa. 25362 & & N/A & 6.2 & 1.6 \\
\hline CA770328 & Tapasin & ABE27285 & GO:00 I9882: antigen presentation & 5.8 & 1.5 \\
\hline CA054633 & ATP-binding cassette transporter 2 & P2।440 & GO:00068I0: transport & 5.5 & 1.7 \\
\hline CB501435* & Omy.3082I & & N/A & 5.4 & 0.6 \\
\hline CA055219(2) & CCAAT/enhancer binding protein beta, & $\mathrm{AAH} 4940 \mathrm{I}$ & GO:0045449: regulation of transcription & 5.0 & 0.8 \\
\hline CA062875 & $\begin{array}{l}\text { Similar to IFN consensus sequence binding } \\
\text { protein IRF-8 }\end{array}$ & Q9087I & GO:0045449: regulation of transcription & 5.0 & 1.4 \\
\hline CB5I7430 & Similar to epithelial stromal interaction I & NP_I 50280.1 & $\mathrm{~N} / \mathrm{A}$ & 4.9 & 1.5 \\
\hline CA053490 & Tumour necrosis factor receptor & CAD57I65 & GO:0007I65: signal transduction & 4.8 & I.I \\
\hline CK990939 & Adipose differentiation-related protein & Q9MZE5 & GO:0016020: membrane & 4.7 & 0.5 \\
\hline
\end{tabular}


Table 2: cDNAs identified as differentially regulated by microarray analysis. Clone ID ${ }^{\prime}$ is the accession number of the cDNA feature on the microarray, when more than one cDNA feature was the same sequence the accession number for the feature with the highest fold difference is given, the number in brackets indicates the number of features identical and used in analysis. Identity ${ }^{2}$ is the functional protein assigned to the cDNA feature, Accession ${ }^{3}$ number relates to the identify of the protein. *indicates cDNA features where protein function is determined from NCBI UniGene as described in the text. Mean is the mean fold difference between the stimulated and non stimulated control cells. (Continued)

\begin{tabular}{|c|c|c|c|c|c|}
\hline CA051393(2) & $\begin{array}{l}\text { Similar to interferon consensus sequence binding } \\
\text { protein }\end{array}$ & NP_990747.I & GO:0045449: regulation of transcription & 4.7 & 1.2 \\
\hline CB5III966 & Factor VIII & Q06194 & GO:0006952: defense response & 4.4 & 0.7 \\
\hline CA04380I & Ssa.22345 & & N/A & 4.4 & 1.2 \\
\hline CA062585 & TAPBP protein... & Q8UUL4 & GO:0019882: antigen presentation & 4.4 & 0.9 \\
\hline CA053654* & Ssa.7103 & & N/A & 4.3 & 0.9 \\
\hline CA060783 & Similar to protein tyrosine phosphatase & NP_035336.I & GO:0006464: protein modification & 4.2 & I.I \\
\hline CB5I5947 & Ssa.13995 & & N/A & 4.2 & 1.0 \\
\hline CB5I56I4 & Ssa.4774 & & $N / A$ & 4.1 & 1.2 \\
\hline CB4979I3 & Omy.8396 & & N/A & 3.9 & 0.4 \\
\hline CB498900 & Ssa. 14843 & & N/A & 3.9 & 1.0 \\
\hline CA7678I5 & sequestosome I & NP_035I48 & GO:0007I65: signal transduction & 3.8 & 0.4 \\
\hline CA05650I & Serine (or cysteine) proteinase inhibitor & Q07235 & $\mathrm{N} / \mathrm{A}$ & 3.7 & 0.7 \\
\hline CA044867 & Ssa.848I & & N/A & 3.7 & 1.0 \\
\hline CB494479 & Transcription factor ETV6 & P97360 & GO:0045449: regulation of transcription & 3.7 & 0.3 \\
\hline CA063565 & Interferon regulatory factor I & AAM77843 & GO:0045449: regulation of transcription & 3.6 & 0.7 \\
\hline CB496486(2) & Low molecular mass protein 7 & P28063 & GO:0006955: immune response & 3.5 & 0.6 \\
\hline CB498525 & Secretory granule proteoglycan core protein & XP_507828.I & N/A & 3.5 & 0.7 \\
\hline CB5I5392 & Stomatin & P54II6 & GO:0007I65: signal transduction & 3.5 & 0.2 \\
\hline CA0527I7 & similar to Fc receptor-like 4 & XP_547521.2 & $\mathrm{N} / \mathrm{A}$ & 3.4 & 0.2 \\
\hline CA052500 & TAPIA & Q9JJ59 & GO:00। 9882: antigen presentation & 3.4 & 0.2 \\
\hline CB494II6 & UNKNOWN & & $\mathrm{N} / \mathrm{A}$ & 3.3 & 0.8 \\
\hline CB489I26 & Protein translation factor SUII & Q9CXU9 & GO:00064I2: protein biosynthesis & 3.2 & 0.3 \\
\hline CK990998(3) & $\begin{array}{l}\text { similar to Protein translation factor SUII } \\
\text { homolog }\end{array}$ & P48024 & GO:00064 I2: protein biosynthesis & 3.2 & 0.3 \\
\hline CA062698 & Ssa. 15825 & & $\mathrm{~N} / \mathrm{A}$ & 3.2 & 0.4 \\
\hline CB499179 & Leucine-rich-repeat protein & XM_039906 & GO:0006952: defense response; & 3.1 & 0.4 \\
\hline CK991328 & Omy.3531 & & N/A & 3.1 & 1.0 \\
\hline CA062450* & Similar to melanoma cell adhesion molecule & NP_075548.I & GO:0007I55: cell adhesion & 3.1 & 0.5 \\
\hline CA05I372 & Low molecular mass protein 2 & Q60692 & GO:0006955: immune response & 3.0 & 0.9 \\
\hline CA057910* & Similar to programmed cell death I ligand I & XP_4248II.I & GO:0006955: immune response & 3.0 & 0.4 \\
\hline CA056074 & $\mathrm{p} 60$ & $\mathrm{AAH} 01874$ & GO:0007I65: signal transduction & 2.9 & 0.3 \\
\hline CB488I80 & ATP synthase & Q9DCX2 & $\begin{array}{l}\text { GO:0015986: ATP synthesis coupled proton } \\
\text { transport }\end{array}$ & 2.9 & 0.2 \\
\hline CA052868 & NADPH oxidase cytosolic protein p40phox & $A B 192468$ & GO:0007I65: signal transduction & 2.9 & 0.3 \\
\hline CA043996* & Ssa.3435 & & N/A & 2.8 & 0.3 \\
\hline CB503379* & Ssa.7962 & & $\mathrm{N} / \mathrm{A}$ & 2.8 & 0.2 \\
\hline CB5।I558 & UNKNOWN & & N/A & 2.7 & 0.3 \\
\hline CA060I76 & Galectin like protein & 008573 & GO:0006952: defense response & 2.6 & 0.2 \\
\hline CB502697* & Transmembrane 4 superfamily member 3 & NP_598210.I & N/A & 2.6 & 0.3 \\
\hline CB498077(4) & Ferritin & P09528 & GO:0006955: immune response & 2.5 & 0.1 \\
\hline CA039745 & Alpha-globin & CAA65955 & GO:00068I0: transport & 2.5 & 0.2 \\
\hline CA062784 & UNKNOWN & & $\mathrm{N} / \mathrm{A}$ & 2.5 & 0.2 \\
\hline CB493I23 & Activating transcription factor 4 & Q6T3V3 & GO:0045449: regulation of transcription & 2.4 & 0.3 \\
\hline CB488782 & Growth regulated nuclear 68 protein & Q61656 & GO:0045449: regulation of transcription & 2.3 & 0.1 \\
\hline \multicolumn{6}{|c|}{ Down regulated by IL-I $\beta$} \\
\hline CA0565I5 & UNKNOWN & & N/A & 5.4 & 2.8 \\
\hline CA04I370 & PREDICTED: similar to MAFB protein & $X P \_4 I 7353 . I$ & GO:0045449: regulation of transcription & 4.7 & 1.7 \\
\hline CA062828(3) & Id 2 protein & P4III36 & GO:0045449: regulation of transcription & 4.0 & 0.4 \\
\hline CB5I4524 & xCDC46 & BAA09949 & GO:0045449: regulation of transcription & 3.3 & 0.4 \\
\hline CB5I7923 & Transforming protein myc & P0II08 & GO:0045449: regulation of transcription & 3.1 & 0.7 \\
\hline CB502538 & UNKNOWN & & N/A & 2.6 & 0.7 \\
\hline CA052685 & Ribonucleotide reductase protein $\mathrm{r} 2$ class $\mathrm{I}$ & PIII57 & GO:0044237 : cellular metabolism & 2.4 & 0.2 \\
\hline
\end{tabular}


mately one. Initial image analysis was performed with the GenPix (version 5.1, Axon instruments) programme and the array images edited to ensure that the GAL (Gene Associated List) file was correctly orientated and that any abnormal hybridization signals were flagged as "bad" and not included in subsequent analysis. Edited images were imported into Acuity (version 5.1, Axon instruments) and analysis performed. All arrays were background corrected using local background correction and normalized using Lowess normalization [87]. The data was filtered to remove bad signal and signal that did not reach a predetermined threshold (signal to noise ratio $>1.5$ for either Cy3 or Cy5). Data sets of genes assigned as up or down regulated were where the gene was significantly different by $t$ test $(\mathrm{P}<0.05)$ and the magnitude of difference was $\geq$ 2 fold increased or decreased. Gene ontology identifiers were used to group genes encoding proteins by function, using the UniProt [89] and the Gene Ontology Consortium [90] web sites maintained by the European Bioinformatics Institute, using both automatic and manual assignment. All GO identifiers are at high level.

\section{Real time PCR gene expression analysis}

Total RNA was collected from cells that were stimulated as described above for 6, 24 and $48 \mathrm{~h}$. For real time PCR, RNA was denatured $\left(65^{\circ} \mathrm{C}, 10 \mathrm{~min}\right)$ in the presence of 1 $\mu$ oligo $\mathrm{dT}_{17}$ primer (500 $\left.\mathrm{ng} \mathrm{l}^{-1}\right)$, the RNA was cooled on ice and cDNA was synthesised using $15 \mathrm{U}$ Bioscript reverse transcriptase (Bioline, UK) in the presence of dNTPs (final concentration $200 \mu \mathrm{M}$ each), at $42^{\circ} \mathrm{C}$ for $1 \mathrm{~h}$ in a final volume of $20 \mu \mathrm{l}$. The cDNA was diluted 5 fold to $100 \mu \mathrm{l}$ and $3 \mu \mathrm{l}$ used as the template for PCR using primers designed against the rainbow trout genes of interest. The chosen clones and their corresponding primers are shown in Table 1. PCR amplification was performed using an Opticon real time PCR machine, using ready prepared $2 \times$ master mix sybre green PCR mix (Biorad) with a final PCR volume of $25 \mu \mathrm{l}$, in white 96 well plates (Biorad). PCR conditions were $95^{\circ} \mathrm{C}$ for 5 min followed by $94^{\circ} \mathrm{C}$ for 20 sec, $57^{\circ} \mathrm{C}$ for $20 \mathrm{sec}$ and $72^{\circ} \mathrm{C}$ for $20 \mathrm{sec}$. The fluorescence signal output was measured and recorded at $78^{\circ} \mathrm{C}$ during each cycle for all wells for 35 cycles. A negative control (no template) reaction was also performed for each primer pair. A sample from the serial dilution was run on a $2 \%$ agarose gel and stained with ethidium bromide and viewed under UV light to confirm a band of the correct size was amplified.

A melting curve for each PCR was determined by reading fluorescence every degree between $55^{\circ} \mathrm{C}$ and $95^{\circ} \mathrm{C}$ to ensure only a single product had been amplified. Two genes previously found to be useful for real time PCR in fish, elongation factor $1 \alpha$ and $\beta$-actin [91] were used as controls for normalization of expression. Neither of these genes were found to be altered in expression on the microarrays in these experiments.

To determine the relative expression level of candidate genes the method of Pfaffl [92] was used to obtain relative expression of candidate genes to both $\beta$ actin and elongation factor $1 \alpha$. Efficiency of amplification was determined for each primer pair using serial 10 fold dilutions of cDNA $(1,10,100 \& 1000$ fold dilutions), performed on the same plate as the experimental samples. The efficiency was calculated as $\mathrm{E}=10^{(-1 / \mathrm{s})}$ where $\mathrm{s}$ is the slope generated from the serial dilutions, when Log dilution is plotted against $\Delta \mathrm{CT}$ (threshold cycle number). For all real time PCRs triplicate reactions were performed.

$$
\text { Ratio }=\frac{\left(\mathrm{E}_{\text {target }}\right)^{\Delta \mathrm{CP}_{\text {Target }} \text { (control-sample) }}}{\left(\mathrm{E}_{\text {ref }}\right)^{\Delta \mathrm{CP}_{\text {ref }} \text { (control-sample) }}}
$$

\section{Statistical analysis}

For microarray studies standard errors of the mean are shown for each selected gene, where a cDNA is represented by more than a single feature the mean and SE for all features is presented. Data was also analysed by t-test within the Acuity software. For real time PCR, data was analysed using t-test for differences between samples and a Pearson correlation to confirm relationships. All micro array data were deposited to the Gene Expression Omnibus data bases [93] series GSE5091 using MIAME [94] guidelines.

\section{Authors' contributions}

SAM performed microarray experiments, analysed the data, carried out the real time PCR and wrote the manuscript. JZ produced the recombinant cytokines, performed the cell stimulations and isolated the RNA. DFH and CJS were involved in the experimental design and drafting of the manuscript. All authors read and approved the final manuscript.

\section{Acknowledgements}

This work was supported by BBSRC grants EGAI 7675 (Salmon TRAITS) and BB/C50602I/I. We thank Ben Koop and Willie Davidson (consortium for Genomics Research on All Salmon Project, cGRASP), for providing the microarrays.

\section{References}

I. Aparicio S, Chapman J, Stupka E, Putnam N, Chia JM, Dehal P, Christoffels A, Rash S, Hoon S, Smit A, Gelpke MD, Roach J, Oh T, Ho IY, Wong M, Detter C, Verhoef F, Predki P, Tay A, Lucas S, Richardson P, Smith SF, Clark MS, Edwards YJ, Doggett N, Zharkikh A, Tavtigian SV, Pruss D, Barnstead M, Evans C, Baden H, Powell J, Glusman G, Rowen L, Hood L, Tan YH, Elgar G, Hawkins T, Venkatesh B, Rokhsar $D$, Brenner S: Whole-genome shotgun assembly and analysis of the genome of Fugu rubripes. Science 2002, 297:130 I-I 3 I0.

2. Jaillon O, Aury JM, Brunet F, Petit JL, Stange-Thomann N, Mauceli E, Bouneau L, Fischer C, Ozouf-Costaz C, Bernot A, Nicaud S, Jaffe D, Fisher S, Lutfalla G, Dossat C, Segurens B, Dasilva C, Salanoubat M, Levy M, Boudet N, Castellano S, Anthouard V, Jubin C, Castelli V, 
Katinka M, Vacherie B, Biemont C, Skalli Z, Cattolico L, Poulain J, De Berardinis V, Cruaud C, Duprat S, Brottier P, Coutanceau JP, Gouzy J, Parra G, Lardier G, Chapple C, McKernan KJ, McEwan P, Bosak S, Kellis M, Volff JN, Guigo R, Zody MC, Mesirov J, Lindblad-Toh K, Birren B, Nusbaum C, Kahn D, Robinson-Rechavi M, Laudet V, Schachter V, Quetier F, Saurin W, Scarpelli C, Wincker P, Lander ES, Weissenbach J, Roest Crollius H: Genome duplication in the teleost fish Tetraodon nigroviridis reveals the early vertebrate protokaryotype. Nature 2004, 43 I:946-957.

3. Postlethwait J, Amores A, Force A, Yan YL: The zebrafish genome. In The Zebrafish: Genetics and Genomics Edited by: Detrich HW, Westerfield M, Zon LI. San Diego, CA: Academic Press; 1999:149-163. [Meth Cell Biol vol 60.]

4. Froschauer A, Braasch I, Volff JN: Fish genomes, comparative genomics and vertebrate evolution. Current Genomics 2006, 7:43-57.

5. Secombes CJ, Wang T, Hong S, Peddie S, Crampe M, Laing KJ, Cunningham $C$, Zou J: Cytokines and innate immunity of fish. Dev Comp Immunol 200I, 25:713-723.

6. Zou J, Cunningham C, Secombes C]: The rainbow trout Oncorhynchus mykiss interleukin-I beta gene has a different organization to mammals and undergoes incomplete splicing. Eur J Biochem 1999, 259:901-908.

7. Engelsma MY, Stet RJ, Saeij JP, Verburg-van Kemenade BM: Differential expression and haplotypic variation of two interleukinI beta genes in the common carp (Cyprinus carpio L.). Cytokine 2003, 22:21-32.

8. Bird S, Zou J, Kono T, Sakai M, Dijkstra JM, Secombes C: Characterisation and expression analysis of interleukin 2 (IL-2) and IL21 homologues in the Japanese pufferfish, Fugu rubripes, following their discovery by synteny. Immunogenetics 2005, 56:909-923.

9. Bird S, Zou J, Savan R, Kono T, Sakai M, Woo J, Secombes CJ: Characterisation and expression analysis of an interleukin 6 homologue in the Japanese pufferfish, Fugu rubripes. Dev Comp Immunol 2005, 29:775-789.

10. Sangrador-Vegas A, Lennington JB, Smith T): Molecular cloning of an IL-8-like CXC chemokine and tissue factor in rainbow trout (Oncorhynchus mykiss) by use of suppression subtractive hybridization. Cytokine 2002, 17:66-70.

II. Zou J, Clark MS, Secombes C): Characterisation, expression and promoter analysis of an interleukin 10 homologue in the puffer fish, Fugu rubripes. Immunogenetics 2003, 55:325-335.

12. Wang TH, Holland JW, Bols N, Secombes CJ: Cloning and expression of the first nonmammalian interleukin-I I gene in rainbow trout Oncorhynchus mykiss. FEBS J 2005, 272: I 36- I I 47.

13. Robertsen B, Bergan V, Rokenes T, Larsen R, Albuquerque A: Atlantic salmon interferon genes: cloning, sequence analysis, expression, and biological activity. J Interferon Cytokine Res 2003, 23:60I-6I2

14. Zou J, Carrington A, Collet B, Dijkstra JM, Yoshiura Y, Bols N, Secombes CJ: Identification and bioactivities of IFN-gamma in rainbow trout Oncorhynchus mykiss: the first Thl-type cytokine characterized functionally in fish. J Immunol 2005 , I 75:2484-2494.

15. Altmann SM, Mellon MT, Distel DL, Kim CH: Molecular and functional analysis of an interferon gene from the zebrafish, Danio rerio. J Virol 2003, 77: 1992-2002.

16. Kono T, Zou J, Bird S, Savan R, Sakai M, Secombes CJ: Identification and expression analysis of lymphotoxin-beta like homologues in rainbow trout Oncorhynchus mykiss. Mol Immunol 2006, 43:|390-|40|.

17. Hardie LJ, Laing KJ, Daniels GD, Grabowski PS, Cunningham C, Secombes C]: Isolation of the first piscine transforming growth factor beta gene: analysis reveals tissue specific expression and a potential regulatory sequence in rainbow trout (Oncorhynchus mykiss). Cytokine 1998, 10:555-563.

18. Laing $\mathrm{KJ}$, Bols N, Secombes $\mathrm{CJ}$ : A CXC chemokine sequence isolated from the rainbow trout Oncorhynchus mykiss resembles the closely related interferon-gamma-inducible chemokines CXCL9, CXCLIO and CXCLII. Eur Cytokine Netw 2002, 13:462-473.

19. DeVries ME, Kelvin AA, Xu L, Ran L, Robinson J, Kelvin DJ: Defining the origins and evolution of the chemokine/chemokine receptor system. J Immunol 2006, I76:40I-I5.
20. Martin SAM, Blaney SC, Houlihan DF, Secombes C): Transcriptome response following administration of a live bacterial vaccine in Atlantic salmon (Salmo salar). Mol Immunol 2006, 43: $|900-| 9||$.

21. Ewart KV, Belanger JC, Williams J, Karakach T, Penny S, Tsoi SC, Richards RC, Douglas SE: Identification of genes differentially expressed in Atlantic salmon (Salmo salar) in response to infection by Aeromonas salmonicida using cDNA microarray technology. Dev Comp Immunol 2005, 29:333-347.

22. Rise ML, Jones SR, Brown GD, von Schalburg KR, Davidson WS, Koop BF: Microarray analyses identify molecular biomarkers of Atlantic salmon macrophage and hematopoietic kidney response to Piscirickettsia salmonis infection. Physiol Genomic 2004, 20:21-35.

23. Gerwick L, Corley-Smith G, Bayne Cl: Gene transcript changes in individual rainbow trout livers following an inflammatory stimulus. Fish Shellfish Immunol 2007, 22:157-I7I.

24. Byon JY, Ohira T, Hirono I, Aoki T: Use of a cDNA microarray to study immunity against viral hemorrhagic septicemia (VHS) in Japanese flounder (Paralichthys olivaceus) following DNA vaccination. Fish Shellfish Immunol 2005, I 8: I 35- I47.

25. Morrison RN, Cooper GA, Koop BF, Rise ML, Bridle AR, Adams MB, Nowak BF: Transcriptome profiling the gills of amoebic gill disease (AGD)-affected Atlantic salmon (Salmo salar L): a role for tumor suppressor $\mathbf{p} 53$ in AGD pathogenesis? Physiol Genomics 2006, 26: I5-34.

26. Roberge C, Paez DJ, Rossignol O, Guderley H, Dodson J, Bernatchez $\mathrm{L}$ : Genome-wide survey of the gene expression response to saprolegniasis in Atlantic salmon. Mol Immunol 2007, 44: $1374-1383$.

27. Byon JY, Ohira T, Hirono I, Aoki T: Comparative immune responses in Japanese flounder, Paralichthys olivaceus, after vaccination with viral hemorrhagic septicemia virus (VHSV) recombinant glycoprotein and DNA vaccine using a microarray analysis. Vaccine 2006, 24:92I-930.

28. Purcell MK, Nichols KM, Winton JR, Kurath G, Thorgaard GH, Wheeler P, Hansen JD, Herwig RP, Park LK: Comprehensive gene expression profiling following DNA vaccination of rainbow trout against infectious hematopoietic necrosis virus. Mol Immunol 2006, 43:2089-2106.

29. Mackenzie S, lliev D, Liarte C, Koskinen H, Planas JV, Goetz FW, Molsa $\mathrm{H}$, Krasnov A, Tort $\mathrm{L}$ : Transcriptional analysis of LPS. stimulated activation of trout (Oncorhynchus mykiss) monocyte/macrophage cells in primary culture treated with cortisol. Mol Immunol 2006, 43: 1340-1348.

30. Hong S, Zou J, Crampe M, Peddie S, Scapigliati G, Bols N, Cunningham $C$, Secombes CJ: The production and bioactivity of rainbow trout (Oncorhynchus mykiss) recombinant IL-I beta. Vet Immunol Immunopathol 200I, 8I:I-I4.

31. Zou J, Peddie S, Scapigliati G, Zhang Y, Bols NC, Ellis AE, Secombes C): Functional characterisation of the recombinant tumor necrosis factors in rainbow trout, Oncorhynchus mykiss. Dev Comp Immunol 2003, 27:813-822.

32. Dinarello CA: The IL-I family and inflammatory diseases. Clin Exp Rheumatol 2002, 20(Suppl 27):SI-13.

33. Mizel SB: The interleukins. FASEB J 1989, 3:2379-2388.

34. Greenfeder SA, Varnell T, Powers G, Lombard-Gillooly K, Shuster D, McIntyre KW, Ryan DE, Levin W, Madison V, Ju G: Insertion of a structural domain of interleukin (IL)-I beta confers agonist activity to the IL-I receptor antagonist Implications for IL-I bioactivity. J Biol Chem 1995, 270:22460-22466.

35. Janssens S, Beyaert R: A universal role for MyD88 in TLR/IL-IRmediated signaling. Trends Biochem Sci 2002, 27:474-482.

36. Heguy A, Baldari CT, Censini S, Ghiara P, Telford JL: A chimeric type II/type I interleukin-I receptor can mediate interleukin1 induction of gene expression in T cells. J Biol Chem 1993, 268: $10490-10494$.

37. Boehm U, Klamp T, Groot M, Howard JC: Cellular responses to interferon-gamma. Annu Rev Immunol 1997, 1 5:749-795.

38. Mosmann TR, Coffman RL: THI and TH2 cells: different patterns of lymphokine secretion lead to different functional properties. Annu Rev Immunol 1989, 7:145-173.

39. Trinchieri G: Proinflammatory and immunoregulatory functions of interleukin- 12. Int Rev Immunol 1998, 16:365-396. 
40. Schroder K, Hertzog PJ, Ravasi T, Hume DA: Interferon-gamma: an overview of signals, mechanisms and functions. J Leukoc Biol 2004, 75:163-189.

4I. Seder RA, Paul WE: Acquisition of lymphokine-producing phenotype by CD4+ T cells. Annu Rev Immunol 1994, I 2:635-673.

42. Yoshida A, Koide $Y$, Uchijima M, Yoshida TO: IFN-gamma induces IL-I 2 mRNA expression by a murine macrophage cell line, J774. Biochem Biophys Res Commun 1994, I 98:857-86I.

43. McGuire K, Glass EJ: The expanding role of microarrays in the investigation of macrophage responses to pathogens. Vet Immunol Immunopathol 2005, I 05:259-275.

44. Bliss TW, Dohms JE, Emara MG, Keeler CL Jr: Gene expression profiling of avian macrophage activation. Vet Immunol Immunopathol 2005, 105:289-299.

45. Wang JP, Rought SE, Corbeil J, Guiney DG: Gene expression profiling detects patterns of human macrophage responses following Mycobacterium tuberculosis infection. FEMS Immunol Med Microbiol 2003, 39: I63-72.

46. Ehrt S, Schnappinger D, Bekiranov S, Drenkow J, Shi S, Gingeras TR, Gaasterland T, Schoolnik G, Nathan C: Reprogramming of the macrophage transcriptome in response to interferongamma and Mycobacterium tuberculosis: signalling roles of nitric oxide synthase-2 and phagocyte oxidase. I Exp Med 200I, I94:II23-II40.

47. Jensen K, Talbot R, Paxton E, Waddington D, Glass EJ: Development and validation of a bovine macrophage specific cDNA microarray. BMC Genomics 2006, 7:224.

48. Hedges JF, Lubick KJ, Jutila MA: Gamma delta $\mathbf{T}$ cells respond directly to pathogen-associated molecular patterns. J Immunol 2005, I 74:6045-53.

49. Ganassin RC, Bols NC: Development of a monocyte/macrophage-like cell line, RTSI I, from rainbow trout spleen. Fish and Shellfish Immunol I 998, 8:457-476.

50. von Schalburg KR, Rise ML, Cooper GA, Brown GD, Gibbs AR, Nelson CC, Davidson WS, Koop BF: Fish and chips: various methodologies demonstrate utility of a 16,006-gene salmonid microarray. BMC Genomics 2005, 6:126.

5I. Laing KJ, Secombes CJ: Trout CC chemokines: comparison of their sequences and expression patterns. Mol Immunol 2004, 41:793-808.

52. NCBI UniGene [http://www.ncbi.nlm.nih.gov/entrez/ query.fcgi?db=unigene)]

53. Pontius JU, Wagner L, Schuler GD: UniGene: a unified view of the transcriptome. 2003 [http://www.ncbi.nlm.nih.gov/books/ bookresfcgi/handbook/ch2I II.pdf]. The NCBI Handbook Bethesda (MD): National Center for Biotechnology Information

54. Rescan PY: Identification in a fish species of two Id (inhibitor of DNA binding/differentiation)-related helix-loop-helix factors expressed in the slow oxidative muscle fibers. Eur J Biochem 1997, 247:870-876.

55. Zou J, Holland J, Pleguezuelos O, Cunningham C, Secombes CJ: Factors influencing the expression of interleukin-I beta in cultured rainbow trout (Oncorhynchus mykiss) leucocytes. Dev Comp Immunol 2000, 24:575-582.

56. Vilcek J: Fifty years of interferon research: aiming at a moving target. Immunity 2006, 25:343-348.

57. Tsoi SCM, Ewart KV, Penny S, Melville K, Liebscher RS, Brown LL, Douglas SE: Identification of immune-relevant genes from Atlantic salmon using suppression subtractive hybridization. Marine Biotechnol 2004, 6:199-214.

58. Douglas SE, Gallant JW, Liebscher RS, Dacanay A, Tsoi SCM: Identification and expression analysis of hepcidin-like antimicrobial peptides in bony fish. Dev Comp Immunol 2003, 27:589-60 I.

59. Shike H, Lauth X, Westerman ME, Ostland VE, Carlberg JM, Van Olst JC, Shimizu C, Bulet P, Burns JC: Bass hepcidin is a novel antimicrobial peptide induced by bacterial challenge. Eur J Biochem 2002, 269:2232-2237.

60. Lee P, Peng H, Gelbart T, Wang L, Beutler E: Regulation of hepcidin transcription by interleukin-I and interleukin-6. Proc Nat Acad Sci USA 2005, 102:1906-1910.

6I. Nemeth E, Rivera S, Gabayan V, Keller C, Taudorf S, Pedersen BK, Ganz T: IL-6 mediates hypoferremia of inflammation by inducing the synthesis of the iron regulatory hormone hepcidin. J Clin Invest 2004, I I 3: I27|- I 276.

62. Courselaud B, Pigeon C, Inoue Y, Inoue J, Gonzalez FJ, Leroyer P Gilot D, Boudjema K, Guguen-Guillouzo C, Brissott P, Loreal O, Ilyin
G: C/EBP alpha regulates hepatic transcription of hepcidin, an antimicrobial peptide and regulator of iron metabolism. J Biol Chem 2002, 277:4 I I63-4II70.

63. Ren HL, Wang KJ, Zhou HL, Yang M: Cloning and organisation analysis of a hepcidin-like gene and cDNA from Japan sea bass, Lateolabrax japonicus. Fish \& Shellfish Immunol 2006, 2 I :22। -227.

64. Fleming RE, Sly WS: Hepcidin: a putative iron-regulatory hormone relevant to hereditary hemochromatosis and the anemia of chronic disease. Proc Natl Acad Sci USA 200I, 98:8780-8785.

65. Shi J, Camus AC: Hepcidins in amphibians and fishes: Antimicrobial peptides or iron-regulatory hormones? Dev Comp Immunol 2006, 30:746-755.

66. Ong ST, Ho JZ, Ho B, Ding JL: Iron-withholding strategy in innate immunity. Immunobiology 2006, 2 I I :295-3 I 4.

67. Pan D, He N, Yang Z, Liu H, Xu X: Differential gene expression profile in hepatopancreas of WSSV-resistant shrimp (Penaeus japonicus) by suppression subtractive hybridization. Dev Comp Immunol 2005, 29: I03-II 2.

68. Konijn AM, Hershko C: Ferritin synthesis in inflammation I Pathogenesis of impaired iron release. $\mathrm{Br} J$ Haematol 1977, 37:7-16

69. Russell S, Lumsden JS: Function and heterogeneity of fish lectins. Vet Immunol Immunopathol 2005, I 08: I I I- I 20.

70. Geijtenbeek TB, van Vliet SJ, Engering A, 't Hart BA, van Kooyk Y: Self- and nonself-recognition by $C$-type lectins on dendritic cells. Annu Rev Immunol 2004, 22:33-54.

7I. Bayne CJ, Gerwick L, Fujiki K, Nakao M, Yano T: Immune-relevant (including acute phase) genes identified in the livers of rainbow trout, Oncorhynchus mykiss, by means of suppression subtractive hybridization. Dev Comp Immunol 200I, 25:205-2 I 7.

72. O'Farrell C, Vaghefi N, Cantonnet M, Buteau B, Boudinot P, Benmansour A: Survey of transcript expression in rainbow trout leukocytes reveals a major contribution of interferonresponsive genes in the early response to a rhabdovirus infection. J Virol 2002, 76:8040-8049.

73. Alonso M, Leong JA: Suppressive subtraction libraries to identify interferon-inducible genes in fish. Marine Biotechnol 2002, 4:74-80.

74. Gantner BN, Simmons RM, Canavera SJ, Akira S: Collaborative induction of inflammatory responses by dectin-I and Tolllike receptor 2. Exp Med 2003, 197: I 107-1 I I7.

75. Matsumoto M, Tanaka T, Kaisho T, Sanjo H, Copeland NG, Gilbert DJ, Jenkins NA, Akira S: A novel LPS-inducible C-type lectin is a transcriptional target of NF-IL6 in macrophages. J Immunol 1999, 163:5039-5048.

76. Imaizumi T, Kumagai M, Sasaki N, Kurotaki H, Mori F, Seki M, Nishi N, Fujimoto K, Tanji K, Shibata T, Tamo W, Matsumiya T, Yoshida H, Cui XF, Takanashi S, Hanada K, Okumura K, Yagihashi S, Wakabayashi K, Nakamura T, Hirashima M, Satoh K: Interferon-gamma stimulates the expression of galectin-9 in cultured human endothelial cells. J Leukoc Biol 2002, 72:486-49I.

77. Zhao Y, Neltner BS, Davis HW: Role of MARCKS in regulating endothelial cell proliferation. Am J Physiol Cell Physiol 2000, 279: $\mathrm{Cl}$ (6II-20.

78. Papas TS, Bhat NK, Spyropoulos DD, Mjaatvedt AE, Vournakis J, Seth A, Watson DK: Functional relationships among ETS gene family members. Leukemia 1997:557-566.

79. Platanias LC: Mechanisms of type-I- and type-II-interferonmediated signalling. Nat Rev Immunol 2005, 5:375-386.

80. Khan S, van den Broek M, Schwarz K, de Giuli R, Diener PA, Groettrup $M$ : Immunoproteasomes largely replace constitutive proteasomes during an antiviral and antibacterial immune response in the liver. I Immunol 2001, 167:6859-6868.

81. Sun SC, Ganchi PA, Ballard DW, Greene WC: NF-kB controls expression of inhibitor IkBa: evidence for an inducible autoregulatory pathway. Science 1993, 259:1912-1915.

82. Hunter CA, Chizzonite R, Remington JS: IL-I beta is required for IL-I 2 to induce production of IFN-gamma by NK cells $A$ role for IL-I beta in the $T$ cell-independent mechanism of resistance against intracellular pathogens. I Immunol 1995 I 55:4347-4354.

83. Steinberg T, Dannewitz B, Tomakidi P, Hoheisel JD, Mussig E, Kohl A, Nees M: Analysis of interleukin-lbeta-modulated mRNA gene transcription in human gingival keratinocytes by epi- 
thelia-specific cDNA microarrays. J Periodontal Res 2006, 4I:426-446.

84. Kota RS, Rutledge JC, Gohil K, Kumar A, Enelow RI, Ramana CV: Regulation of gene expression in RAW 264.7 macrophage cell line by interferon-gamma. Biochem Biophys Res Commu 2006, 342: II37-II 46.

85. Halonen SK, Woods T, Mclnnerney K, Weiss LM: Microarray analysis of IFN-gamma response genes in astrocytes. J Neuroimmunol 2006, I75: 19-30.

86. Robertsen B, Zou J, Secombes CJ, Leong JA: Molecular and expression analysis of an interferon-gamma-inducible guanylatebinding protein from rainbow trout (Oncorhynchus mykiss). Dev Comp Immunol 2006, 30: 1023-1033.

87. GRASP [http://web.uvic.ca/cbr/grasp/GAL 16006.gal]

88. Yang YH, Dudoit S, Luu P, Lin DM, Peng V, Ngai J, Speed TP: Normalization for CDNA microarray data: a robust composite method addressing single and multiple slide systematic variation. Nucleic Acids Res 2002, 30:el 5.

89. UniProt [http://www.pir.uniprot.org]

90. GenOntology Consortium [http://www.geneontology.org/]

91. Jorgensen SM, Kleveland EJ, Grimholt U, Gjoen T: Validation of reference genes for real-time polymerase chain reaction studies in Atlantic salmon. Mar Biotechnol 2006, 8:398-408.

92. Pfaffl MW: A new mathematical model for relative quantification in real-time RT-PCR. Nucleic Acids Res 200I, 29:e45.

93. Gene Expression Omnibus data bases [http:// www.ncbi.nlm.nih.gov/geo]

94. Brazma A, Hingamp P, Quackenbush J, Sherlock G, Spellman P, Stoeckert C, Aach J, Ansorge W, Ball CA, Causton HC, Gaasterland T, Glenisson P, Holstege FC, Kim IF, Markowitz V, Matese JC, Parkinson H, Robinson A, Sarkans U, Schulze-Kremer S, Stewart J, Taylor R, Vilo J, Vingron M: Minimum information about a microarray experiment (MIAME)-toward standards for microarray data. Nat Genet 200I, 29:365-37I.

Publish with Bio Med Central and every scientist can read your work free of charge

"BioMed Central will be the most significant development for disseminating the results of biomedical research in our lifetime. "

Sir Paul Nurse, Cancer Research UK

Your research papers will be:

- available free of charge to the entire biomedical community

- peer reviewed and published immediately upon acceptance

- cited in PubMed and archived on PubMed Central

- yours - you keep the copyright

Submit your manuscript here:

http://www.biomedcentral.com/info/publishing_adv.asp
BiolMedcentral 